Title: A long-term study of new particle formation in a coastal environment: Meteorology, gas phase and solar radiation implications

Author(s): Sorribas, M.; Adame, J. A.; Olmo, F. J.; Vilaplana, J.M., Gil-Ojeda, M., AladosArboledas, L.

Source: Science of the Total Environment Volume: 511 Pages: 723-737 Published: APR 12015 DOI: 10.1016/j.scitotenv.2014.12.011 


\title{
A LONG-TERM STUDY OF NEW PARTICLE FORMATION IN A COASTAL ENVIRONMENT: METEOROLOGY, GAS PHASE AND SOLAR RADIATION IMPLICATIONS
}

\author{
Sorribas, M. ${ }^{1,2}$, Adame, J.A. ${ }^{3}$, Olmo, F.J. ${ }^{1,2}$, Vilaplana, J.M. ${ }^{3}$, Gil-Ojeda, M. ${ }^{3}$, and Alados- \\ Arboledas, L. 1,2
}

[1] Department of Applied Physics, University of Granada, Granada, 18071, Spain

[2] Andalusian Institute for Earth System Research (IISTA), University of Granada, 18006, Spain

[3] 'El Arenosillo' - Atmospheric Sounding Station, Atmospheric Research and Instrumentation

Branch, National Institute for Aerospace Technology (INTA), Mazagón-Huelva, 21130, Spain

Corresponding author: Mar Sorribas (sorribas@ugr.es)

\begin{abstract}
New particle formation (NPF) was investigated at a coastal background site in Southwest Spain over a four-year period using a Scanning Particle Mobility Sizer (SMPS). The goals of the study were to characterise the NPF and to investigate their relationship to meteorology, gas phase $\left(\mathrm{O}_{3}\right.$, $\mathrm{SO}_{2}, \mathrm{CO}$ and $\mathrm{NO}_{2}$ ) and solar radiation (UVA, UVB and global). A methodology for identifying and classifying the NPF was implemented using the wind direction and modal concentrations as inputs. NPF events showed a frequency of $24 \%$ of the total days analyzed. The mean duration was $9.2 \pm 4.2$ hours. Contrary to previous studies conducted in other locations, the NPF frequency reached its maximum during cold seasons for approximately $30 \%$ of the days. The lowest frequency took place in July with $10 \%$, and the seasonal wind pattern was found to be the most important parameter influencing the NPF frequency. The mean formation rate was $2.2 \pm 1.7 \mathrm{~cm}^{-3}$ $\mathrm{s}^{-1}$, with a maximum in the spring and early autumn and a minimum during the summer and winter. The mean growth rate was $3.8 \pm 2.4 \mathrm{~nm} \mathrm{~h}^{-1}$ with higher values occurring from spring to autumn. The mean and seasonal formation and growth rates are in agreement with previous observations from continental sites in the Northern Hemisphere. NPF classification of different classes was conducted to explore the effect of synoptic and regional-scale patterns on NPF and growth. The results show that under a breeze regime, the temperature indirectly affects NPF events. Higher temperatures increase the strength of the breeze recirculation, favouring gas accumulation and subsequent NPF appearance. Additionally, the role of high relative humidity in inhibiting the NPF was evinced during synoptic scenarios. The remaining meteorological variables $(\mathrm{RH})$, trace gases ( $\mathrm{CO}$ and $\mathrm{NO}$ ), solar radiation, $\mathrm{PM}_{10}$ and condensation sink, showed a moderate or high connection with both formation and growth rates.
\end{abstract}

\section{Highlights:}

- New particle formation (NPF) was observed over 4-years in the South-western Spain

- New particle formation events showed a frequency of $24 \%$ of the total days analyzed

- NPF was more frequent in cold seasons and less frequent in summer time 
- NPF parameters were different under synoptic or regional-scale atmospheric patterns

- Formation and growth rates were dependent on the solar radiation and gas levels

Keywords: New particle formation, meteorological variables, solar radiation, trace gases, formation and growth rates

\section{INTRODUCTION}

Atmospheric particles contribute to light absorption, scattering of solar radiation and cloud formation, which are key processes of the global climate system. Homogeneous nucleation of supersaturated vapour plays an important role in the atmospheric particle concentration. Although the impact of secondary particle formation on the global climate is highly uncertain, it could be potentially large and opposite of the warming effect of greenhouse gases (IPCC, 2014). Furthermore, the seasonal total concentration cycle is better simulated by including the nucleation mechanism than by increasing emissions from primary sources (Spracklen et al., 2010). In recent years, the potential effect of aerosols on the climate has been corroborated by studies linking new particle formation (NPF) events with modifications to aerosol scattering processes (Shen et al., 2011) and with the aerosol number acting as cloud condensation nuclei (CCN) (Yum et al., 2007; Spracklen et al., 2008).

NPF through homogeneous gas-phase processes, followed by the condensation growth of the freshly nucleated particles to detectable sizes, occurs frequently in the atmosphere (e.g., Kulmala et al., 2004a). The particle formation mechanisms have been studied in detail (e.g., Kulmala et al., 2004a; 2004b; 2006), but the number of global observations is still very limited. These measurements have been performed over short periods (e.g., Jeong et al., 2010; Mahajan et al., 2011; Young et al., 2013) or as part of long-term monitoring programs (e.g., Dal Maso et al., 2005; Hirsikko et al., 2012; Cusack et al., 2013). Although these studies have been conducted, the influence on the NPF processes of the nucleation mechanisms, chemical species or meteorological variables have not been completely clarified. The most previously studied mechanisms examined include binary nucleation by water and sulphuric acid (e.g., Nilsson and Kulmala, 1998), ternary nucleation that involucrates water, sulphuric acid and ammonia (e.g., Korhonen et al., 1999) and ion-induced nucleation (e.g., Mahajan et al., 2011).

Although studies of NPF events based on long-term observations have increased in Europe in recent years, very few studies have been conducted in Spain. A previous study focusing on the daily and seasonal variability of particle number size distribution and the importance of NPF events in the absence of a significant condensation sink was conducted in a regional background area in Northwest Spain (Cusack et al., 2013). Additionally, a climatology study of NPF events in the subtropical North Atlantic free troposphere of Tenerife Island was presented in García et al. (2014), which evinced a clearly marked NPF season from May to August with an occurrence frequency of approximately $55 \%$ of total days/months.

A preliminary study of NPF events in Southwest Spain was reported by Sorribas et al. (2011). This work stated that nucleation events segregate depending on the wind direction during the hours preceding the nucleation burst and in terms of the source region. Based on these more recent results, the goals of the present paper are as follows: (1) to examine the long-term occurrence and duration of NPF in this coastal area, (2) to explore the formation and growth rates of newly formed particles, (3) to determine the meteorological variables values and trace gas concentrations under which NPF events occur, and (4) to determine the variables that influence nucleation and growth rates. 


\section{EXPERIMENTAL SETUP}

\subsection{Sampling site}

The 'El Arenosillo' Atmospheric Sounding Station is located in Southwest Spain along the Atlantic Coast and close to the Mediterranean Sea and the North African Coast (Fig. 1). This observatory delivers data to the World Ozone and Ultraviolet Radiation Data Centre (WOUDC) and World Data Centre for Aerosols (WDCA) of the Global Atmosphere Watch (GAW) program developed by the World Meteorological Organization (WMO). The most recent results regarding this observatory can be found in Prats et al. (2008), Córdoba-Jabonero et al. (2011), Sorribas et al. (2011), Antón et al. (2012) and Adame et al. (2014) among others.

\section{Fig.1}

The measurement site is situated in the protected rural environment of the Doñana National Park and is less than $1 \mathrm{~km}$ away from the coastline. The sector lying north-north-west and east-southeast (NNW and ESE) (Fig. 1) has been identified as the 'sector with Predominance of Biogenic Emissions' (Adame et al., 2014), and it will be referred to throughout this work as the PBE sector. The majority of the land coverage in the PBE sector is composed of forest (60.2\%), followed by crops (35.5\%), urban and industrial activities (3.9\%) and water environments $(0.4 \%)$. Additionally, the land coverage beside the PBE sector and Atlantic Coast is also composed of the forest area, but other anthropogenic emissions from Huelva City and the industrial and dock areas surrounding the city could alter the levels of biogenic emissions. The PBE sector was selected based on the requirements of our study, which will be presented in greater detail in Section 3.1.

Regarding the main aerosol types, typical atmospheric synoptic patterns over the sampling site cause the arrival of coastal marine, continental and desert dust air masses (Hernández-Ceballos, et al., 2013). Additionally, as the sampling site is located in a coastal area, frequent mesoscale processes can develop, inhibiting air mass renovation and favouring gas and aerosol accumulation. Adame et al. (2010) identified the existence of two sea-land breeze patterns called pure and non-pure breeze. In this study, only the scenarios under pure breeze (a typical coastal recirculation process) have been considered. The criterion applied for identification of these processes is the same as used in the previous mentioned work. This pattern is characterised by wind occurring during the land regime from the PBE sector (land to sea and perpendicular to the coast). In the morning, after a clockwise rotation, the wind blows in the opposite direction (sea to land) within sector ESE-W. Although in this pattern the sea and land breeze occurs in the periods of 12:00-17:00 UTC and 3:00-8:00 UTC, respectively, the time before the start of the sea/land breeze is variable.

From June 2004 to September 2009, the surface aerosol and gas measurements at El Arenosillo were collected using a sampling inlet placed $8 \mathrm{~m}$ above ground level and $3 \mathrm{~m}$ above the canopy. The aerosol sampling method was conducted according to Sheridan et al. (2001) with a flow rate of $980 \mathrm{l} \mathrm{min}^{-1}$ and a Reynolds Number ( $R e$ ) of 13650 and using a vertical stainless steel pipe (9.8 $\mathrm{cm}$ inner diameter and $550 \mathrm{~cm}$ length). The outer pipe was positioned concentrically around an inner pipe with a $1 \mathrm{~cm}$ inner diameter and length of $120 \mathrm{~cm}$, and the aerosol sample was transported into the laboratory with an open curve. The flow rate and $R e$ in-pipe were $13.3 \mathrm{l} \mathrm{min}^{-}$ ${ }^{1}$ and 1820, respectively, and the aerosol was directed first to the flow splitter and then to the SMPS particle spectrometer. From October 2009 to the present, a new aerosol sampling system design was used. The system consists of a vertical stainless steel pipe $(2.3 \mathrm{~cm}$ inner diameter and $300 \mathrm{~cm}$ length), which directs the aerosol first into the flow splitter and then into the SMPS at a flow rate of $15 \mathrm{l} \mathrm{min}^{-1}$ and a $R e=900$. The sampling system efficiency was calculated according 
to Willeke and Baron (1993), and ranged from 85\% for $16.5 \mathrm{~nm}$ particles to $94 \%$ for $604 \mathrm{~nm}$ particles.

\subsection{Datasets}

\subsubsection{Sub-micrometre particle number size distribution}

The dry ambient sub-micrometre particle number size distribution was monitored using a Scanning Mobility Particle Sizer (SMPS) (Electrostatic Classifier TSI Mod. 3080). A particle counter (TSI Mod 3022A) was used until May 2008 and was later replaced with an ultrafine particle counter (TSI Mod 3776). The data were obtained within a 14.3-675.3 nm size range using aerosol and sheath flow rates of 0.3 and $3.0 \mathrm{l} \mathrm{min}^{-1}$, respectively. The particle spectrometer uses the particle mobility to calculate the particle mobility diameter (D) (Knutson and Whitby, 1975). The system maintenance was performed according to the standard procedures (Wiedensohler et al., 2012). Each year, the accuracy of the Differential Mobility Analyzer (DMA) size selection was tested using polystyrene latex spheres following the REDMAAS (Spanish Network on Environmental DMAs) guidelines (Gómez-Moreno et al., 2013). The particle diameters obtained were within $2 \%$ of the diameter sizes expected.

From July 2004 to July 2012, the SMPS was operational during a total of 4.3 years and 1326 days of valid data are available. Gaps in the database occurred due to technical problems or through use of the instrumentation in campaigns outside of El Arenosillo. All of the spectra were checked and inaccurate measurements were removed, and more than 160000 valid size distributions were obtained. The datasets were corrected for losses caused by diffusion processes and by multiple charges within the instrument.

A quality criterion was defined and applied to the dataset: a day was un-considered if no data were found over a period longer than four hours from 06:00 GMT to 18:00 GMT. Applying this criterion, a total of 1215 days remained; i.e., $8.7 \%$ of the total days were removed. The number of relevant days per month for the entire 4-year measurement interval was $101 \pm 28$ days with a maximum of 143 days during March and minimum of 52 days during October. The number of days during October is rather small, and its representative character will be discussed separately.

For this study, particle number size distributions were assumed to have three-size fractions: the nucleation size fraction (14-30 nm), which was only occasionally present in the size distributions and for a limited time interval, the Aitken size fraction (30-100 nm) and the accumulation size fraction (100-673 nm). The particle concentrations within these three size fractions are denoted by $\mathrm{N}_{\mathrm{NUC}}, \mathrm{N}_{\mathrm{AIT}}$ and $\mathrm{N}_{\mathrm{ACC}}$, respectively. The term "mode" was used to describe each mode of the size distribution function when it was log-normal fitted.

\subsubsection{Gas phase and meteorological data}

Gas phase concentrations $\left(\mathrm{O}_{3}, \mathrm{NO}_{2}, \mathrm{NO}, \mathrm{SO}_{2}\right.$ and $\left.\mathrm{CO}\right)$, particle matter concentration $\left(\mathrm{PM}_{10}\right)$, meteorological variables (wind speed (WS), wind direction (WD), relative humidity (RH) and air temperature (T)) and ultraviolet (UVA and UVB) and global solar radiation are used in this study. While $\mathrm{O}_{3}, \mathrm{NO}_{2}$, $\mathrm{NO}$, solar radiation and meteorological variables were measured in El Arenosillo, $\mathrm{SO}_{2}, \mathrm{CO}$, and $\mathrm{PM}_{10}$ were collected in an air quality station located $8 \mathrm{~km}$ to the northwest of the site (Mazagón).

The $\mathrm{PM}_{10}$ measurements were conducted using an instrument based on the attenuation of betaradiation (FAG FH-62-N) that was equipped with a $\mathrm{PM}_{10}$ inlet. Ozone measurements with a Dasibi 1008 RS were based on the absorption of ultraviolet radiation by ozone at $254 \mathrm{~nm}$, using a flow rate of $2 \mathrm{l} \mathrm{min}^{-1}$. The $\mathrm{NO}_{\mathrm{x}}$ data were collected with a sensitivity chemiluminescence 
detector (API Model 200E) that conducted simultaneous in situ measurements of $\mathrm{NO}$ and $\mathrm{NO}_{2}$. The precision and detection limit for all of the analysers was set to $1 \mathrm{ppb}$. The $\mathrm{SO}_{2}$ concentrations were measured using ultraviolet fluorescence (Thermo Model 43A), and CO measurements were obtained via non-dispersive infrared spectroscopy (Teledyne TAPI 300E). A Vaisala Sensor (Model VXT 520) was used to measure surface meteorological variables. Additionally, UV and global radiation levels were observed using a Brewer MK-III spectroradiometer and a Kipp-Zonen CMP-21 piranometer (automatic radiometric station of the State Agency of Meteorology). All datasets were manually inspected for the identification and removal of instrument malfunctions, and hourly values were evaluated by applying a quality criterion of $85 \%$.

\section{METHODOLOGY}

\subsection{Identification and classification of the new particle formation episodes}

The identification of NPF events began with a search for wind directions suitable for the study (see Fig. 2). In a previous work, NPF events were classified under airflows coming from the PBE sector and others (Sorribas et al., 2011). In the work presented here, the objective is to identify NPF events caused by biogenic emissions, i.e., through wind-blowing from the PBE sector. Data collected on days with wind blowing outside of this sector were labelled 'un-considered.' As Huelva City is located a close distance from the PBE sector (Fig. 1), flows from the PBE sector may have been previously affected by anthropogenic emissions on certain days. These cases were classified under the 'Mixed' sector.

The next step was to examine the pure sea-land breeze and the synoptic scenario influences on the NPF events (Fig. 2). In pure sea-land breeze processes, the biogenic precursor gases travel from the PBE sector to the sea and accumulate in the upper residual layers at night. By sunrise, the nucleation process begins to surge over both land and sea, simultaneously. Consequently, a subset of days was obtained, and the following criteria were applied to this set to extract days with NPF events (Fig. 2).

Although varying forms of criteria have been used to classify NPF events in previous studies, a subjective visual inspection of particle concentration evolution has always been necessary (Boy and Kulmala, 2002; Dal Maso et al., 2005; Jeong et al., 2010). The methodology for identifying and classifying NPF events presented in Dal Maso et al. (2005) and later applied in other studies (e.g., Cheung et al., 2011; Hirsikko et al., 2012) was used as the basis for the decision path flowchart used in our analysis (Fig. 2).

To identify NPF events, the evolution of particle size distribution was visually inspected daily through 24 h-colour surface plotting. Then, the particle concentration evolution for nucleation and Aitken size fractions were analysed ( $\mathrm{N}_{\mathrm{NUC}}$ and $\left.\mathrm{N}_{\mathrm{AIT}}\right)$. A NPF event is defined as an increase in $\mathrm{N}_{\mathrm{NUC}}$ of higher than $1000 \mathrm{~cm}^{-3}$ over a period of at least one hour between sunrise and sunset. The newly formed particles of sizes ranging between 14 and $30 \mathrm{~nm}$ appear roughly at noon and grow at a rate of a few nanometres per hour into larger-mode particles. In cases where new particles of the nucleation size fraction do not grow to larger diameters, the days are labelled 'undefined.'

Fig. 2

Through the application of the above mentioned criteria, a set of NPF events was obtained. These events are classified into three classes according to their origin: (1) Class NB (Non Breeze) occurs under a synoptic flow from the PBE sector; (2) Class LB (Land Breeze) occurs 
during the land regime and continues throughout the marine breeze; and (3) Class SB (Sea Breeze) occurs during the sea breeze regime. As Fig. 2 shows, in cases where an NPF event was observed only under a land flow, this NPF event was added to the flowchart as a Class NB event given that the NPF characteristics were not influenced by the atmospheric recirculation.

Next, the classification flowchart (Fig. 2) shows a set of criteria used to detect clear NPF events. Class $k$-I events ( $k$ value corresponds to the acronyms NB, LB or SB) are clear and strong NPF events, in which the typical shape of a NPF event (banana shape) is observable and where particle formation and growth rates can be easily determined. All other events, in which the $\mathrm{N}_{\mathrm{NUC}}$ and mode diameter fluctuate and result in an impractical evaluation of the formation and growth rates, are classified as Class $k$-II events. Fig. 3 shows the 24h-colour surface plot for specific days that were selected to illustrate differences between Class $k-1$, Class $k-2$ and the undefined events discussed previously.

Fig. 3

\subsection{Evaluation of properties for new particle formation events}

\subsubsection{Formation and growth rates}

One of the most relevant variables for identifying NPF events is the growth rate (GR), which is defined as the diameter rate of change due to particle population growth. This parameter is shown by $\left(\mathrm{nm} \cdot \mathrm{h}^{-1}\right)$ and can be evaluated using different methods. The most commonly applied and recently used methods have been maximum-concentration and log-normal distribution function methods (Jeong et al., 2010; Shen et al., 2011). The log-normal distribution function method is suitable for estimating the GR for particle diameters greater than $\sim 5 \mathrm{~nm}$, and the maximum-concentration method is most effectively applied to lower diameters (Hirsikko et al., 2012; Pikridas et al., 2012). The limitations of each method (Dal Maso et al., 2005; Kulmala et al., 2012) and comparisons between them (Yli-Juuti et al., 2011) are described in the literature. Given that the lowest-diameter particle included in our work is larger than $5 \mathrm{~nm}$, the GR value evaluated in this work was derived from the log-normal distribution function method.

All 10-min particle number size distributions were fitted with 2 log-normal modes, which allowed for the calculation of modal parameters (the geometric mean diameter $\mathrm{D}_{\mathrm{g}}$, the number concentration $\mathrm{N}$ and the geometric standard deviation $\sigma_{\mathrm{g}}$ ). The growth rate was computed using the geometric mean diameter of the nucleation mode:

$G R=\frac{\Delta D_{g}}{\Delta t}=\frac{D_{g 2}-D_{g 1}}{t_{2}-t_{1}}$

where $D_{g 1}$ and $D_{g 2}$ are the geometric mean diameters at times $t_{1}$ and $t_{2}$, respectively.

For this study, the GR was calculated for two size-dependent fractions: (1) for particle growth within the lower diameter (14 nm) and the maximum diameter (mean GR); and (2) for particle growth within the nucleation size range $\left(\mathrm{GR}_{14-30}\right)$.

The formation rate (or nucleation rate) is defined as the newly formed particle production rate during a given time (Dal Maso et al., 2005; Vakkari et al., 2011; Kulmala et al., 2012; Young et al., 2013). The unit for this variable is denoted by $\mathrm{cm}^{-3} \cdot \mathrm{s}^{-1}$. Formation rates for $14 \mathrm{~nm}$ particles $\left(\mathrm{J}_{14}\right)$ were computed following Dal Maso et al. (2005, and references therein), and using the Eq. (2): 


$$
J_{14}=\frac{d N[14-30 n m]}{d t}+\text { losses }=\frac{d N_{N U C}}{d t}+F_{\text {coag }}+F_{\text {growth }}=\frac{d N_{N U C}}{d t}+\operatorname{CoagS}_{N U C} \cdot N_{N U C}
$$

where $\mathrm{N}[14-30 \mathrm{~nm}]$ is the concentration of the nucleation size fraction $\left(\mathrm{N}_{\mathrm{NUC}}\right)$, CoagS $\mathrm{NUC}_{\mathrm{C}}$ is the particle removal rate due to coagulation processes in the nucleation size fraction (more information is provided in Section 3.2.4) and $F_{\text {growth }}$ is the flux in particle growth outside of the nucleation size fraction. The growth term is neglected in our study due to the assumption that particles rarely grow larger than $30 \mathrm{~nm}$ before a formation event ends (Dal Maso et al., 2005; Hirsikko et al., 2012). A mean value of $F_{\text {coag }}$ over the observed formation event was also considered.

\subsubsection{Condensation and coagulation sinks}

A condensation sink (CS) denotes the ability of the particle size distribution to remove condensable vapour from the atmosphere. This variable is proportional to the surface area density of an aerosol particle. Elevated pre-existing particles can suppress aerosol nucleation by scavenging newly nucleated particles and condensable vapour. Sulphuric acid $\left(\mathrm{H}_{2} \mathrm{SO}_{4}\right)$ was assigned as the condensable species, and the CS of the transition regime was calculated according to Dal Maso et al. (2005, and references therein) and using a diffusion coefficient of $0.104 \mathrm{~cm}^{2} \mathrm{~s}^{-1}$ (Kanawade et al., 2011; Young et al., 2013) and a transition regime factor for mass transfer considering a gas vapour molecule mean free path of $123 \mathrm{~nm}$ (Erupe et al., 2010).

Coagulation is the process of aerosol collisional growth. It is characterised by the coagulation sink (CoagS), which describes an aerosol population's ability to remove particles of size $\mathrm{D}$. The variable can be determined from Dal Maso et al. (2005) and Kulmala et al. (2012) using the particle number size distribution and the coagulation coefficient. The coagulation coefficient is calculated in our work from a Boltzmann constant of $1.38 \times 10^{-23} \mathrm{~J} \mathrm{~K}^{-1}$, a standard temperature of $293 \mathrm{~K}$, a viscosity coefficient of $1.83 \times 10^{-5} \mathrm{~Pa} \cdot \mathrm{s}$ and a mean free path of $0.0686 \mu \mathrm{m}$ (Baron and Willeke, 2001).

\subsubsection{Estimation of sulphuric acid}

To obtain information on the relationship of sulphuric acid to new particle formation events and their subsequent growth, the sulphuric acid concentration was estimated according to Petäjä et al. (2009) using the following expression:

$$
\mathrm{H}_{2} \mathrm{SO}_{4}=k_{3} \frac{\left[\mathrm{SO}_{2}\right] \cdot \mathrm{Glob}}{\mathrm{CS}}
$$

where $\mathrm{SO}_{2}$ is the measured sulphur dioxide concentration for molecules $\mathrm{cm}^{-3}$, Glob is the measured global solar radiation for $\mathrm{W} \mathrm{m} \mathrm{m}^{-2}$, CS is the condensation sink for $\mathrm{s}^{-1}$ and $\mathrm{k}_{3}$ is the empirical scaling factor evaluated by:

$$
k_{3}=8.4 \cdot 10^{-8} \cdot G l o b^{-0.68}
$$

with a $\mathrm{k}_{3}$ of $\mathrm{m}^{2} \mathrm{~W}^{-1} \mathrm{~s}^{-1}$. This scaling factor was computed based on measurements recorded in a boreal forest, and thus the absolute values are not valid for Southwest Spain. Despite this uncertainty, the measurements provide valuable information on sulphuric acid annual cycles.

\section{RESULTS AND DISCUSSION}

\subsection{Overview of new particle formation events}




\subsubsection{NPF event frequency}

Table 1 shows the number of days and frequency (based on total and sector days) of the dataset classified previously through application of the mentioned criteria (Section 3.1). Of the 1215 days included, 608 (50\%) were obtained from the PBE sector, and the rest of the days comprise the sum of the mixed sector and un-considered days. The 608 days were classified as non-event (244 days, 20.1\%), event (289 days, 23.8\%) and undefined (75 days, 6.1\%). If only data collected from the PBE sector are considered (a total of 608 days), the event frequency rises to $47.6 \%$ with Class NB, Class LB and Class SB values of (17.8\%), (18.8\%) and (11.0\%), respectively. This increase is due to the classification of the NPF episodes shown in Section 3.1, where Classes NB, LB and SB events occur with the wind-blowing from the PBE sector.

\section{Table 1}

In El Arenosillo, the frequency of total NPF event days was similar to findings reported from other locations, including the Finnish boreal forest (Dal Maso et al., 2005) and a semi-rural continental environment in U.S. (Kanawade et al., 2011). However, the frequency was found to be lower than frequencies observed in locations such as the Northeast Atlantic (33\%) (Dall'Osto et al., 2011), industrial and agricultural areas of the Po Valley (Italy) (36\%) (Hamed et al., 2007), the Australian eucalyptus forest (52\%) (Suni et al., 2008) and the semi-clean savannah of South Africa (69\%) (Vakkari et al., 2011). The highest frequency level was found in the western Bushveld Igneous Complex (86\%) (Hirsikko et al., 2012). In contrast, in the Central European (Germany) (Birmili et al, 2000) and Antarctic areas (Asmi et al., 2010), the annual nucleation event frequency was found to be lower than that of El Arenosillo, with an average value of approximately 20\%. The lowest value was found on the Asian continent (7.5\%) (Kim et al., 2013). These differences between the frequencies of NPF processes in other locations worldwide are attributed to various factors such as the emissions strengths of precursor gases, the composition and number concentration of pre-existing aerosols, meteorological variables and photochemical processes.

The monthly evolution of NPF events (using 289 days with regards to the total 1215 days) has been investigated (Fig. 4a). The maximum number of days was obtained during the autumn (November and December) and winter (February and March) months with a value of 30\% of the days. The lowest frequency was recorded in July at $\sim 10 \%$. With regards to non-event days (over 244 days), the monthly distribution shows that the highest proportion occurred in January ( $\sim 57 \%$ of days) and the lowest proportion occurred in May ( 18\%) (Fig. $4 \mathrm{~b})$. The percentage of undefined days was lower than $8 \%$ with the exception of November and December when the percentage rose to approximately $11 \%$ (Fig. 4c).

Fig. 4

Depending on the geographic distribution of the new aerosol source, the wind direction may be the most important variable influencing the NPF event frequency at a given site. Fig. 4d shows the monthly frequency of wind blowing from the PBE sector, which is the evolution expected given that this area typically involves flows from the Northeast during cold seasons. The typical meteorological scenarios in the cold season in Western Europe are suitable for the arrival of northern flows to the Iberian Peninsula, i.e., atmospheric transport from Central Europe. These flows reach the southern of the Iberian Peninsula (where the measurement station is located) and are channelled through the Guadalquivir valley (Hernández-Ceballos et al., 2013).

Fig. 4a and 4d demonstrate a similar pattern because NPF events were selected by applying the $\mathrm{PBE}$ sector wind condition. For the days with the wind blowing from the PBE sector (using the 
289 days with regards to the 608 sector days), the monthly distribution of NPF events is shown in Fig. 4e. The maximum frequency occurs during the spring and early summer (March-July) with a value of approximately $60 \%$ of the days. The maximum frequency is associated with a high frequency of processes such as photochemical activity and mesoscale movement (Adame et al., 2010). However, a second relative maximum value of $47 \%$ appears during late autumn (November and December). This may be a result of certain biogenic emissions in the area (more studies on this behaviour are currently being conducted). Finally, lower frequencies were found in the late summer and early autumn (September) and during the winter (January) when values fell below $40 \%$ of the days.

Aerosol measurements from the literature collected in different environments describe elevated NPF occurrences in the spring and minimum values in the summer and winter: e.g., in rural central Europe (Birmili et al., 2003), in a clean area of Southern Finland (Dal Maso et al., 2005), in a rural area in the eastern part of the Po Valley (Italy) (Hamed et al., 2007), in a semi-rural, continental environment of the U.S. (Kanawade et al., 2011) and in urban areas (Borsós et al., 2012). The results obtained for El Arenosillo, with air blowing from the PBE sector (Fig. 4e), corroborate this behaviour. However, in the winter, the occurrence was higher than the other sites, reaching a frequency of approximately $40 \%$ of the days, whereas in rural central Europe the value was $25 \%$ of the days, in the Po Valley the percentage was $15 \%$ and in the semi-rural environment of the U.S. and in Southern Finland the percentage was lower than $10 \%$. This result could be due to a higher incoming solar radiation level during winter in southern Europe.

The NPF event monthly frequency by class is shown in Fig. 4f. The NB events are observed during the cold seasons, and LB and SB events occurred year-round but at a higher frequency during the warm seasons. Although sea-land breezes can occur at any time of the year in this coastal area, these processes occurred from May to September at a frequency higher than 30\% (Adame et al., 2010). The results exhibited in Fig. 4f are in agreement with atmospheric circulation patterns in this area. NPF events without a breeze primarily occur in the cold seasons, and NPF events associated with a breeze are recorded in the warm seasons with peaks during the mid-summer months.

\subsubsection{NPF event parameters}

Table 2 shows parameters relevant for NPF characterisation such as start and end times ( $\mathrm{t}_{\text {start }}$ and $t_{\text {end }}$ ), event duration $(\Delta t)$, the contribution of coagulation loss flux ( $\left.F_{\text {coag }}\right)$ formation and growth rates (J, mean GR and $\mathrm{GR}_{14-30}$ ) and the maximum concentration for the nucleation size fraction $\left(\mathrm{N}_{\max }\right)$ and the maximum diameter during the growth process $\left(\mathrm{D}_{\max }\right)$. All variables are presented in terms of the event class. More information on monthly variations in formations and growth rates and of $\mathrm{N}_{\max }$ and $\mathrm{D}_{\max }$ are provided in Fig. 5.

Although the newly formed particles form at particle size of $1 \mathrm{~nm}$ (see Kulmala et al., 2013), the particles need time to grow to $14 \mathrm{~nm}$, which is the minimum size detectable by our instrument. The time parameter $t_{\text {start }}$ could be shifted to more realistic values by taking into account the mean GR as $t_{\text {start }}($ at $1 \mathrm{~nm})=\mathrm{t}_{\text {start }}$ (at $\left.14 \mathrm{~nm}\right)-\mathrm{GR} \cdot(14-1)$. However, the disadvantage of the proposed method for the present data sets is that the $\mathrm{GR}_{14-30}$ is evaluated within a size range, which is far from the (1-14) nm relevant diameter interval. Given that the exact formation time at the $1 \mathrm{~nm}$ particle size is not known, $t_{\text {start }}$ is defined in the present work as the time when $\mathrm{N}_{\mathrm{NUC}}$ begins to increase. $T_{\text {end }}$ is the time at which particle growth stops. The growth stop was calculated as the moment that the regression fit, between geometric mean diameter of particle size $(\mathrm{nm})$ versus time (hour) measured during a NPF event, has a roughly null slope. Accordingly, the duration $(\Delta t)$ was estimated as the difference between $t_{\text {start }}$ and $t_{\text {end. }}$. The mean for $t_{\text {start }}$ and $\Delta t$ are also shown in Table 2 by the event class. The values for all classes were 11:30 \pm 01:40 GMT and 9.2 \pm 4.2 hours, respectively (' \pm ' means standard deviation in this study). The Class LB events 
occurred at the earliest times and Class SB events occurred at the latest times with a difference in time of $\sim 1 \mathrm{~h}$. This result is in agreement with sea-land breeze behaviour as the sea regime started when the land regime finished. Therefore, Class LB events occur before Class SB events. Regarding duration, Class NB events were the longest and required $10.7 \pm 3.3 \mathrm{~h}$, and Class SB events were the quickest.

The mean observed formation rate for the $14 \mathrm{~nm}$ particles $\left(\mathrm{J}_{14}\right)$ was $2.2 \pm 1.7 \mathrm{~cm}^{-3} \mathrm{~s}^{-1}$ and the median was $1.5 \mathrm{~cm}^{-3} \mathrm{~s}^{-1}$, varying from 0.5 (10 $10^{\text {th }}$ percentile) to $4.4\left(90^{\text {th }}\right.$ percentile) $\mathrm{cm}^{-3} \mathrm{~s}^{-1} . A$ review of the formation rates of $10 \mathrm{~nm}$ particles, $J_{10}$, is shown in Kulmala et al. (2004), which finds a typical formation rate in the continental boundary layer from 0.01 to $10 \mathrm{~cm}^{-3} \mathrm{~s}^{-1}$, whereas at least an order of magnitude higher can be reached in coastal zones. It was expected that El Arenosillo would produce similar formation rates as other coastal locations around the world. However, taking into account the wind direction during the hours prior to the NPF event, new particle formation aerosol sources are mainly biogenic and continental, and the formation rates are closer to observations from continental boundary sites than to the levels at coastal sites.

\section{Table 2}

The monthly variation (Fig. 5a) in $\mathrm{J}_{14}$ shows peaks in the spring (April and May) and early autumn (October) and a minimum during the summer and winter. The number of days during October for the whole 4-year measurement interval was small (see Section 2.2.1) and therefore, the low representativeness of the peak observed during early autumn must be considered. The same seasonal evolution has been found in previous observations of the Northern Hemisphere such as in Hyytiälä (Finland) (Dal Maso et al., 2005), the North China Plain (Shen et al., 2011), the Po Valley (Italy) (Hamed et al., 2007) and the South African savannah (Vakkari et al., 2011). These similarities in monthly cycles of $\mathrm{J}_{14}$ in other locations worldwide are related to different combinations of chemical, physical and meteorological processes which define the production rate of new particles in the atmosphere.

If NPF is observed during land breeze processes, recirculation patterns could not influence the formation rate given that similar $\mathrm{J}_{14}$ values are evinced during $\mathrm{LB}$ and $\mathrm{NB}$ events with values of $2.5 \pm 2.3 \mathrm{~cm}^{-3} \mathrm{~s}^{-1}$ and $2.2 \pm 1.7 \mathrm{~cm}^{-3} \mathrm{~s}^{-1}$, respectively (see Table 2). However, if NPF is observed during sea breeze processes (SB days), the formation rates remain at lower values $\left(\mathrm{J}_{14}=1.7 \pm 1.3\right.$ $\mathrm{cm}^{-3} \mathrm{~s}^{-1}$ ). The existence of biogenic precursor gases accumulated overnight offshore in addition to probable emission contributions from ship engines appear to be the most feasible causes of the NPF events observed during the SB days. Less favourable atmospheric conditions for particle formation during the SB days, such as higher relative humidity, could have caused the lower $\mathrm{J}_{14}$ values.

The mean particle growth rate (mean GR) was $3.8 \pm 2.4 \mathrm{~nm} \mathrm{~h}^{-1}$, and the median rate was $3.2 \mathrm{~nm}$ $\mathrm{h}^{-1}$, and varied between $1.6\left(10^{\text {th }}\right.$ percentile) and $6.6\left(90^{\text {th }}\right.$ percentile) $\mathrm{nm} \mathrm{h}^{-1}$. Similar mean GR values were found in earlier observations of rural, continental and background environments conducted by different authors and summarised by Yli-Juuti et al. (2011). The El Arenosillo values of mean GR are also within the range of growth rates found by Kulmala et al. (2004) for unpolluted rural locations, which typically range from 1 to $10 \mathrm{~nm} \mathrm{~h}^{-1}$. Larger values representative of rural polluted sites were not found, confirming our assumption that polluted precursor gases have little or no influence on NPF events from the PBE sector. The growth rate usually decreases in time, although the mean GR and $\mathrm{GR}_{14-30}$ observed at El Arenosillo were similar. This behaviour could be related to how the $\mathrm{GR}_{14-30}$ is evaluated within a size range, which is quite far from the initial size of the new particle, where the differences in growth rate between the different particle sizes are higher (Hirsikko et al., 2012). 
Particle growth rates (mean GR) are higher from spring to autumn and reach a maximum in September (Fig. 5b). This is corroborated with annual variations of mean GR found in previous studies (e.g., Dal Maso, et al., 2005; Shen et al., 2011; Vakkari et al., 2011). This observation can be attributed to the enhancement of photochemical and biological processes during the summer months. However, the high frequency of sea-land breeze processes (Adame et al., 2010) and increase in atmospheric stagnation, preventing exchange with cleaner air masses and encouraging particle and gases accumulation (Querol et al., 2008), could provide another explanation. Under these conditions, particle growth is assisted by the condensation of volatile vapour, increasing the efficiency of the particle growth processes. This is also supported by the differences found between mean GR levels during days involving sea-land breeze processes and synoptic patterns. A similar value of mean GR was found for the days involving sea-land breeze processes (LB and SB days), reaching $4.5 \pm 3.0 \mathrm{~nm} \mathrm{~h}^{-1}$ and $4.4 \pm 2.6 \mathrm{~nm} \mathrm{~h}^{-1}$, respectively (Table 2). However, the mean GR observed for the days involving synoptic conditions (NB days) was lower at a value of $2.9 \pm 1.1 \mathrm{~nm} \mathrm{~h}^{-1}$.

The contribution of the coagulation loss flux $\left(\mathrm{F}_{\mathrm{coag}}\right)$ was $12 \pm 6 \%$ of the appearance rate, indicating that the directly observable formation rate was approximately $88 \%$ of the real appearance rate. The $\mathrm{F}_{\text {coag }}$ value was lower than those found for continental sites such as Hyytiälä, Finland (30\%) (Dal Maso et al., 2005), urban areas such as in Beijing, China (41\%) (Yue et al., 2009), and in several sites of central Taiwan (45-80\%) (Young et al., 2013).

The mean condensation sink (not shown in Table 2), CS, was $9.3 \cdot 10^{-3} \pm 6.5 \cdot 10^{-3} \mathrm{~s}^{-1}$, which is in the range of CS values reported in the literature for rural environments (Vakkari et al., 2011; Yli-Juuti et al., 2011). The value of the condensation sink, which is largely a function of the larger particle number concentration, may be used as an indicator of air quality. The lowest CS values of $10^{-4} \mathrm{~s}^{-1}$ are found in very clean areas such as remote environments. In contrast, the highest values of $10^{-2} \mathrm{~s}^{-1}$ are found in urban and polluted areas (Lunden et al., 2006; Yue et al., 2009).

\subsection{Environmental conditions favouring the NPF frequency}

Hourly average concentrations of meteorological, trace gases and particle parameters for event and non-event days were considered to analyse the effect of each variable on the frequency of the new particle formation processes.

\subsubsection{Particle parameters influencing on NPF}

Fig. 6 shows the hourly average evolution of $\mathrm{N}_{\mathrm{NUC}}, \mathrm{CS}$ and $\mathrm{PM}_{10}$ on breeze days (both with Class LB and Class SB events and without events (Class Non-Event-LSB) - Fig. 6 top) and under synoptic patterns (with Class NB events and without events (Class Non-Event-NB) - Fig. 6 bottom). The diurnal evolution of hourly mean particle concentration for the nucleation size fraction, $\mathrm{N}_{\mathrm{NUC}}$, on events days deviated from non-event days from 05:00-23:00 GMT for Class LB events, from 09:00-19:00 GMT for Class SB events and from the full daily evolution for Class NB events (Figs. 6a and 6d). The maximum value at noon is similar for both Class LB and Class NB events, although Class LB event frequency was higher during the warm seasons, and Class NB event frequently was higher during the cold seasons (Fig. 4f).

An increase in $\mathrm{N}_{\mathrm{NUC}}$ is observed at approximately 6:00 UTC for the Class LB events, and this is not detected in the other cases. This increase may be attributed to the land-to-sea regime transition, with calms occurring for one to two hours that favour accumulation in the lower layers or inversion layer breakdown and new particle formation in the mixing layer. This pattern, 
which may suggest that different environmental conditions favour new particle formation, will be studied in greater detail in future studies.

Fig. 6

On average, the condensation sink, CS, was slightly higher on non-event days (Class Non-EventLSB and Class Non-Event-NB events) during the morning and midday periods (Fig. 6b y 6e). This behaviour was expected given that a low CS value favours new particle formation because particle growth is possible before particles coagulate with larger particles (Hamed et al., 2007). Under synoptic patterns (Fig. 6e), this trend changed in the afternoon, and slightly higher CS values were found on event days.

The hourly mean of $\mathrm{PM}_{10}$ concentration (particles smaller than $10 \mu \mathrm{m}$ ) was observed to be similar on days with synoptic patterns (Fig. 6f) regardless of whether NPF events were observed. However, differences were detected on days involving atmospheric recirculation (Fig. 6c) with larger $\mathrm{PM}_{10}$ concentrations produced during Class SB events than Class LB events. When particle mass concentration is larger, the greater particle surface acts as a sink for many gases such as $\mathrm{SO}_{2}$, potentially inhibiting the NPF event or modifying the formation rate, $\mathrm{J}_{14}$, toward lower values. This may explain why Class LB events were observed one hour earlier than Class SB events (Table 2). Additionally, it was observed that on non-event days (Non-event-LSB days), the $\mathrm{PM}_{10}$ concentration was higher than during Class LB and Class SB events, from 05:00 GMT to 11:00 GMT. Therefore, a few hours before the $t_{\text {start }}$ is shown in Table 2. This behaviour has also been reported in previous studies (e.g., Shen et al., 2011; Hirsikko et al., 2012).

\subsubsection{Meteorological variables influencing on NPF}

The temperature, relative humidity, wind speed and solar radiation records overtop of the station are analysed to determine whether the diurnal patterns are correlated with the different types of NPF events (Fig. 7).

Under the sea-land breeze scenarios, NPF events occur at higher temperatures than on non-event days, suggesting that temperature affects the nucleation process. However, the fact that no temperature dependence was found under the synoptic situations (non-breeze scenarios) (Fig. 7b) provides evidence that temperature does not have a direct affect. As mentioned previously, the breeze regime is a regional scenario that acts as a close circuit gas reservoir. Therefore, under a persistent breeze regimen, gas accumulation rises and the likelihood of NPF increases. As breeze strength is temperature dependent, so is the chances for NPF events. Additionally, the high temperatures and gas accumulation allow photochemical processes to initiate the nucleation process. However, large-scale winds under synoptic conditions do not allow sufficient time to accumulate enough gas and trigger NPF mechanisms. There is currently no consensus on the role played by temperature. Whereas nucleation events have previously been associated with high temperatures in central Europe (Birmili et al., 2003; Hamed et al., 2007), the opposite has been found to be true at various environmentally pristine locations in Finland (Boy and Kulmala, 2002; Vehkamäki et al., 2004) and in the Sierra Nevada Mountains of California (Lunden et al., 2006).

Under sea-land breeze conditions, the difference in relative humidity between NPF days and non-events days could be attributed to differences in temperature evolution. But, this is insufficient evidence to prove that relative humidity does not affect NPF events directly. A hypothesis regarding how the high relative humidity is directly inhibiting the NPF in breeze conditions is that if the water content of the air is similar during event and non-events days; when temperatures are lower, the RH is higher and therefore, NPF is not occurring. However, under synoptic conditions, lower RH levels may trigger NPF events. Although the role of 
relative humidity in new particle formation has been studied extensively in multiple locations, as with temperature, no conclusive results currently exist. However, although high relative humidity levels may increase the number of newly formed particles, a broader research community argues that high relative humidity levels would reduce the number of particles through various mechanisms described by Hamed et al. (2011) and references therein: (1) preexisting aerosol particles absorb water vapour as RH levels increase (hygroscopic growth) producing a larger-surface particle (and high condensation sink, CS), which can be used by condensable vapour, such as gases, as precursors to newly formed particles; (2) high RH levels are also related to increased coagulation scavenging of newly formed particles onto pre-existing particles; and (3) RH levels are higher on cloudy days given that there is less incoming solar radiation to drive photochemical reactions for the formation of gas precursors.

\section{Fig. 7}

The wind speed was determined to be similar on event and non-event days, independent of the atmospheric pattern (Fig. 7c and 7f). Thus, NPF can occur under wind speeds between 3 and $5 \mathrm{~m}$ $\mathrm{s}^{-1}$; i.e., low-medium values are a necessary condition to avoid atmospheric dispersion. As was expected, the wind speed is higher under synoptic than mesoscale conditions. This behaviour was also observed in various sampling sites in Finland (Boy and Kulmala, 2002; Komppula et al., 2003). However, observations of higher wind speeds on event days can also be found in the literature (Lunden et al., 2006; Hamed et al, 2007).

Fig. 8 illustrates that global solar radiation levels were higher on event days than non-event days. The UVA and UVB levels (not shown in Fig. 8) exhibit a similar behaviour. The results show that NPF events occur on cloudless days, which is apparently due to the large rates of hydroxyl radical formation present when photochemistry processes are more likely. This positive correlation between solar radiation and NPF events is the common feature found across all nucleation studies (e.g., Boy and Kulmala, 2002; Komppula et al., 2003; Vehkamäki et al., 2004). However, Fig. 8 shows that the noon maximum solar radiation level was higher during Class LB and SB events than during Class NB events. This occurred because Class LB and SB event frequencies are higher during warm seasons but Class NB events are more frequent during cold events. The frequency of NPF events was independent of the spectral bands of incoming solar radiation (UVA, UVB and global). Therefore, it would be sufficient to use, for instance, one of the spectral ranges analysed to characterise the NPF frequency at El Arenosillo.

Fig. 8

\subsubsection{The influence of trace gases and $\mathrm{H}_{2} \mathrm{SO}_{4}$ on NPF events}

The relationship between trace gases $\left(\mathrm{O}_{3}, \mathrm{SO}_{2}, \mathrm{CO}\right.$ and $\left.\mathrm{NO}_{2}\right)$, sulphuric acid concentration $\left(\mathrm{H}_{2} \mathrm{SO}_{4}\right)$ and NPF classes was examined in terms of diurnal patterns (Fig. 9 and 10). Surface $\mathrm{O}_{3}$ is the most representative species of photochemical activity. $\mathrm{CO}$ and $\mathrm{NO}_{2}$ are tracers of polluted air masses and are involved in photochemical cycles. $\mathrm{CO}$ can be associated with long and intermediate-range transport ( $>10 \mathrm{~km}$ from source), whereas $\mathrm{NO}_{2}$ is an indicator of short-range transport ( $<10 \mathrm{~km}$ from source). Moreover, $\mathrm{SO}_{2}$ concentrations are analysed due to the central role that this gas plays in $\mathrm{H}_{2} \mathrm{SO}_{4}$ production as a particle precursor.

As was expected and previously demonstrated (Adame et al., 2010), daily ozone cycles show higher values under breeze conditions than under synoptic conditions. Under breeze conditions, NPF events occur under ozone level conditions $\sim 15 \mu \mathrm{g} \mathrm{m}^{-3}$ higher than ozone levels present during non-events. However, under synoptic flow conditions, the differences between event and non-event days are lower, $\sim 7 \mu \mathrm{g} \mathrm{m}^{-3}$. In both scenarios, $\mathrm{O}_{3}$ was observed to be higher on event days, highlighting that major photochemical activity occurred to initiate NPF (Fig. 9a and 9e). 
This result suggests that ozone may be a driving force behind both indirect and direct nucleation processes. Ozone indirectly affects processes because it favours the production of $\mathrm{H}_{2} \mathrm{SO}_{4}$ via $\mathrm{O}_{3}$ photolysis, the production of hydroxyl radicals and subsequent reaction with $\mathrm{SO}_{2}$ (Berndt et al., 2010). The gas has a direct effect given that it is responsible for condensable species formation through reaction with VOCs, which may be related to the growth of newly formed molecular clusters at detectable sizes (Gómez-Martín et al., 2013). In contrast, higher $\mathrm{O}_{3}$ concentrations are correlated with more efficient photochemical processes, which are related to an intensified production of new particles.

Fig. $9 \mathrm{~b}$ and $9 \mathrm{f}$ show the daily cycle of $\mathrm{SO}_{2}$ concentrations. As was expected, the $\mathrm{SO}_{2}$ values are low across all cases in this natural environment (between 5 and $7 \mu \mathrm{g} \mathrm{m}^{-3}$ ) compared to other industrial areas in Spain (Adame et al., 2012). Depending on each event type, differences in $\mathrm{SO}_{2}$ concentrations of 2-3 $\mu \mathrm{g} \mathrm{m}^{-3}$ can be found. Given that $\mathrm{SO}_{2}$ takes part in the production of $\mathrm{H}_{2} \mathrm{SO}_{4}$, larger $\mathrm{SO}_{2}$ concentrations should be expected on event days. However, the observations at El Arenosillo station show that this natural interpretation cannot always be assumed. Class LB events showed similar levels to those of non-event days. However, days with Class SB events exhibited higher $\mathrm{SO}_{2}$ concentrations than non-event days (Fig. 9b).

There are various anthropogenic and natural sources of $\mathrm{SO}_{2}$ concentrations such as industrial activities, fuel combustion, volcanoes and dimethyl sulphide (DMS) oxidation. $\mathrm{SO}_{2}$ levels observed during Class SB events are hypothesised to have resulted from the combined effect of ship engine exhaust emissions, industrial areas surrounding Huelva City and DMS oxidation. In any case, it is necessary to acquire more comprehensive information to draw conclusions on $\mathrm{SO}_{2}$ concentrations during Class SB events.

\section{Fig. 9}

During Class NB events, the daily evolution of $\mathrm{SO}_{2}$ shows that the concentration of this gas was lower on event days, suggesting that $\mathrm{SO}_{2}$ did not contribute to new particle formation (Fig. 9f). $\mathrm{SO}_{2}$ is the precursor of significant vapour $\mathrm{H}_{2} \mathrm{SO}_{4}$ nucleation, and even when it is present in lower concentrations but in the presence of factors favouring event occurrence (lower relative humidity (Fig. 7e) and higher solar isolation (Fig. 8)) it can produce NPF events (Lyubovtseva et al., 2005). Furthermore, during Non-NB days, elevated concentrations of $\mathrm{SO}_{2}$ do not necessarily warrant greater production of the nucleating vapour $\mathrm{H}_{2} \mathrm{SO}_{4}$.

With respect to sea-land breezes (Fig. 9c), the highest differences in CO concentrations ( 100 $\mu \mathrm{g}$ $\mathrm{m}^{-3}$ ) between event and non-event days are found nocturnally, and this could be due to differences in vertical stability. If vertical mixing is elevated, advection movements may be inhibited and CO concentrations may be lower. Therefore, NPF events may be associated with days of minor mixing intensity in the evening prior to the nucleation burst. CO peaks were obtained in the early morning and late evening to identify similar processes at suburban stations. It should be noted that $\mathrm{CO}$ and $\mathrm{SO}_{2}$ concentrations were monitored at a station located in the Mazagón Village situated 8 km from El Arenosillo. Under synoptic flows (Fig. 9g), the peaks are more pronounced and there are few observed differences across NPF and non-events. However, differences in $\mathrm{NO}_{2}$ daily pattern values under breeze and synoptic conditions with both NPF events and non-events are not significant (Fig. 9d and 9h), implying little or no influence of nitrogen oxides on the NPF process.

Finally, Fig. 10 shows that sulphuric acid concentrations are related to the occurrence of NPF events. Under sea-land breeze atmospheric circulations, $\mathrm{H}_{2} \mathrm{SO}_{4}$ concentrations in the early morning were slightly higher on event days than non-event days. In addition, the maximum concentration for each class event was independent of NPF occurrence at $\sim 7 \cdot 10^{6}$ molec. $\mathrm{cm}^{-3}$ 
(Fig. 10a). However, during synoptic situations, event days showed higher $\mathrm{H}_{2} \mathrm{SO}_{4}$ concentrations for nearly all of the days with peak concentrations of $\sim 1.1 \cdot 10^{7}$ molec. $\mathrm{cm}^{-3}$, except at 13:00 GMT when a peak concentration was observed during non-event days (Fig. 10b).

\section{Fig. 10}

\subsection{Conditions favouring the formation and the growth rates}

Pearson's correlation coefficients (R) have been evaluated for each pair of variables considered in the study to explore the connections between formation and growth rates under the environmental conditions shown in the previous section (Table 3).

The mean value of each variable (T, RH, WS, etc) was calculated during the period of particle formation for each NPF event. Then, the Pearson's correlation coefficients between $\mathrm{J}_{14}$ and each variable were calculated using the inventory of NPF events. The same rule applies for the two growth rates, mean GR and $\mathrm{GR}_{14-30}$ because each variable was either calculated for the total NPF duration (see Table 2) or during the period of growth from $14 \mathrm{~nm}$ to $30 \mathrm{~nm}$, respectively. The meteorological variables that did not show significant linear correlations with the formation and growth rates for the three class events were temperature and wind speed (WS). With respect to trace gases, no correlation with $\mathrm{NO}_{2}$ and $\mathrm{O}_{3}$ was observed. In contrast, the particle concentration for the nucleation size fraction was positive and highly correlated with the formation rate, $\mathrm{J}_{14}$, for all class events (as was expected). In other words, higher formation rates produce higher $\mathrm{N}_{\mathrm{NUC}}$ values. The remaining variables showed a moderate or high correlation with $\mathrm{J}_{14}, \mathrm{GR}_{14-30}$ and mean GR depending on the class event, and these will be discussed below.

A positive and high correlation was found between the formation rate, $\mathrm{J}_{14}$, and $\mathrm{PM}_{10}$ concentration for Class NB events. Previous studies in this area have shown that a particle concentration increase in the accumulation size fraction $\left(\mathrm{N}_{\mathrm{ACC}}\right)$ leads to a sharp decrease in $\mathrm{N}_{\mathrm{NUC}}$ and a suppression of new particle formation (Sorribas et al., 2011). In this sense and as suggested through the correlation found between $\mathrm{J}_{14}$ and $\mathrm{PM}_{10}$, a relationship may exist between the formation rate and particles of diameters greater than those within the accumulation size fraction, that is, particles within the coarse mode $(\mathrm{D}>1 \mu \mathrm{m})$. This could explain why higher formation rates, $\mathrm{J}_{14}$, were related to air masses from the PBE sector during all day containing natural aerosols, such as pollen and other natural components, which may accompany them as biogenic volatile organic components (BVOCs). Although the high values of $\mathrm{PM}_{10}$ were associated with large surface area concentrations, which favoured the condensation of gases onto pre-existing particles and suppressed the NPF, large amounts of precursor BVOCs may favour the NPF and increase of the formation rate. Following this hypothesis, during Class LB and SB events the wind was not blowing from the PBE sector during the entire day and therefore, the correlation between $\mathrm{J}_{14}$ and $\mathrm{PM}_{10}$ was not observed. However, the particle growth rate (mean GR) during Class NB events was found to be connected with global solar radiation, but the $\mathrm{GR}_{14-30}$ did not correlate with any spectral ranges of solar radiation.

In the early morning hours of Class LB events, particles formed with a formation rate, $\mathrm{J}_{14}$, which was positively and moderately correlated with UVA and UVB radiation. However, this relationship was observed only during Class LB events (Table 3). During the first stage of particle growth from $14 \mathrm{~nm}$ to $30 \mathrm{~nm}\left(\mathrm{GR}_{14-30}\right)$, airflow came from the PBE sector. In contrast, and according to this dataset, there is a positive and moderate correlation between $\mathrm{GR}_{14-30}$ and CS. This could indicate that under sea-land breeze patterns, a simultaneous accumulation of particles (within the accumulation size fraction) and gas, creates condensing vapour that is most likely coupled with high CS values. Similar behaviour has also been observed at Juangfraujoch station (Boulon et al., 2010). If the atmospheric recirculation is not observed, as during Class NB events, there is not an accumulation of particles and gas and the correlation between $\mathrm{GR}_{14-30}$ and 
CS is not observed. In this sense, the negative and high correlation between $\mathrm{GR}_{14-30}$ and $\mathrm{PM}_{10}$ suggests an inhibition of the particle growth process: however, a confirmation based on more detailed studies would be required. A hypothesis may be that the large surface area favoured the condensation of precursor gases onto pre-existing particles and suppressed the NPF. Finally, $\mathrm{GR}_{14-30}$ is also positive and moderately correlated with ultraviolet solar radiation and more specifically with lower wavelengths such as UVB.

\section{Table 3}

According to Table 3, the relationship between diverse variables and the formation and growth rates during Class SB events was also studied. When the particles are formed, the formation rate, $\mathrm{J}_{14}$, is positively and moderately correlated with global radiation and CO concentrations. CO may originate from long-range or local transport. In the last case, ship emissions or aged industrial emissions may have accumulated over the sea in residual layers. However, the correlation between $\mathrm{J}_{14}$ and CO is not observed for Class NB and LB events. Further analysis and complementary data are necessary to clarify this point. During particle growth, $\mathrm{GR}_{14-30}$ and mean GR are positively and moderately correlated with the condensation sink (CS). Higher vapour source rates or higher relative humidity combined with higher condensation sinks may cause this relationship. This may also explain the observed correlation between relative humidity and GR. Similar results were observed in Lyubovtseva et al. (2005).

\section{CONCLUSIONS}

New particle formation (NPF) at a coastal background site of Southwest Spain was studied over a four-year period. NPF events showed a frequency of $24 \%$ of the total number of days. Most of the events (30\%) occurred in the autumn months (November and December) and in the winter (February and March). The lowest probability was found in July when only $10 \%$ of the days showed NPF events, and seasonal wind patterns were the most important factor influencing NPF frequency during this period. In other environments around the world, opposite seasonal NPF frequency patterns were found. The mean formation rate was $2.2 \pm 1.7 \mathrm{~cm}^{-3} \mathrm{~s}^{-1}$, showing a maximum value in the spring and early autumn and a minimum value during the summer and winter months. The mean particle growth rate was $3.8 \pm 2.4 \mathrm{~nm} \mathrm{~h}^{-1}$ with higher values occurring from spring to autumn. The same mean and seasonal evolution values for formation and growth rates have been found in previous observations of continental sites in the Northern Hemisphere.

NPF event classification for three different classes was conducted to find the effect of synoptic and regional-scale atmospheric patterns on NPF and growth. Class NB events were observed under the synoptic conditions where wind blew from the Predominance of Biogenic Emissions (PBE) sector for a full day. Class LB events and Class SB events were then observed under sealand conditions and land and sea regimes, respectively.

Whereas Class NB events were more frequent during the cold seasons under low relative humidity conditions, Class LB and SB events occurred in warmer seasons under high temperatures. Although the highest temperatures did not directly affect the NPF process during Class LB and SB events, there is a cause-and-effect relationship: the breeze regime acts as a closed circuit, increasing gas accumulation and thus the likelihood for NPF event occurrence. Given that breeze strength is temperature-dependent, so is the likelihood for NPF events. Additionally, high temperatures and the gas accumulation rates favour photochemical processes that initiate the nucleation process.

During the Class NB condition, elevated concentrations of $\mathrm{SO}_{2}$ do not necessarily ensure a high production of the $\mathrm{H}_{2} \mathrm{SO}_{4}$ nucleating vapour if less favourable conditions are present (high 
relative humidity and low solar isolation). Rather, among the Class $\mathrm{SB}$ events, $\mathrm{SO}_{2}$ concentrations were higher on event days.

During Class NB events, the formation rates are correlated with $\mathrm{PM}_{10}$ concentrations, suggesting a relationship with natural aerosols, such as pollen and other natural components, which may accompany them as VOCs. However, during Class LB and SB events, growth rates (GR $\mathrm{GR}_{14-30}$ and mean GR) were positively and moderately correlated with the condensation sink. The results also suggest that during the Class LB events, the simultaneous accumulation of particles and gases created condensing vapour that was most likely coupled with high CS levels. Rather, this relationship is consistent with higher vapour source rates or higher relative humidity levels combined with higher condensation sinks (or higher levels of accumulated particles) during Class SB events.

Acknowledgments - M. Sorribas would like to thank MINECO for the postdoctoral grant award (Juan de la Cierva). This work was partially supported by the Andalusian Regional Government through projects P10-RNM-6299 and P12-RNM-2409, the Spanish Ministry of Science and Technology (MINECO) through projects CGL2010-18782, CGL2011-24891/CLI, CGL2013-45410-R and the Complementary Action CGL2011-15008-E, and European Union through the ACTRIS project (EU INFRA-2010-1.1.16262254). We would also like to thank to the Andalusia Autonomous Government for $\mathrm{PM}_{10}, \mathrm{SO}_{2}$ and $\mathrm{CO}$ data of Mazagón Station and the Spanish Meteorology Agency (AEMET) for global solar radiation data.

\section{References}

Adame, J.A., Serrano, E., Bolívar, J.P., and De la Morena, B.A. 2010. On the tropospheric ozone variations in a coastal are of South-western Europe under a Mesoscale Circulation, J. Appl. Meteorol. Climatol., 49, 748-759, doi:10.1175/2009JAMC2097.1.

Adame, J.A., Notario, A., Villanueva, F., Albaladejo, J. 2012. Application of cluster analysis to surface ozone, NO2 and SO2 daily patterns in an industrial area in Central-Southern Spain measured with a DOAS system. Science of the Total Environment 429, 281-291. doi:10.1016/j.scitotenv.2012.04.032.

Adame, J.A., Martínez, M., Sorribas, M., Hidalgo, P., Harder, H., Diesch, J.-M., Drewnick, F., Song, W., Williams, J., Sinha, V., Hernández-Ceballos, M.A., Vilà-Guerau de Arellano, J., Sander, R., Hosaynali-Beygi, Z., Fischer, H., Lelieveld, J., and De la Morena, B. 2014. Meteorology during the DOMINO campaign and its connection with trace gases and aerosols. Atmos. Chem. Phys., 14, 2325-2342.

Antón, M., Sorribas, M., Bennouna, Y., Vilaplana, J.M., Cachorro, V.E., Gröbner, J. and AladosArboledas. 2012. Effects of an extreme desert dust event on th espectral ultravioleta irradiance at El Arenosillo (Spain). J. Geophys. Res., 117, D03205, doi:10.1029/2011JD016645.

Asmi, E., Frey, A., Virkkula, A., Ehn, M., Manninen, H.E., Timonen, H., Tolonen-Kivimäki, O., Aurela, M., Hillamo, R., and Kulmala, M. 2010. Hygroscopicity and chemical composition of Antarctic sub-micrometre aerosol particles and observations of new particle formation. Atmos. Chem. Phys., 10, 4253-4271.

Baron, P.A., Willeke, K. 2001. Aerosol measurements: principles, techniques and applications. Ed. Willey, 1131 pages, ISBN: 0-471-35636-O.

Berndt, T., Stratmann, F., Sipila, M., Vanhanen, J., Petaja, T., Mikkila, J., Gruner, A., Spindler, G., Mauldin, R. L., III, Curtius, J., Kulmala, M., Heintzenberg, J. 2010. Laboratory study on new 
particle formation from reaction $\mathrm{OH}+\mathrm{SO} 2$ : influence of experimental conditions, $\mathrm{H} 2 \mathrm{O}$ vapour, NH3 and the amine tert butylamine on the overall process. Atmos. Chem. Phys., 10, 7101-7116.

Birmili, W., and Wiedensohler, A. 2000. New particle formation in the continental boundary layer: meteorological and gas phase parameter influence. Geophys. Res. Lett., 27, 3325-3328.

Birmili, W., Berresheim, H., Plas-Dülmer, C., Elste, T., Gilge, S., Wiedensohler, A., and Uhrner, U. 2003. The Hohenpeissenberg aerosol formation experimental (HAFEX): a long-term study including size-resolved aerosol, $\mathrm{H}_{2} \mathrm{SO}_{4}, \mathrm{OH}$, and monoterpenes measurements. Atmos. Chem. Phys., 3, 361-376.

Borsós, T., Rimnácová, D., Zdímal, V., Smolík, J., Wagner, Z., Weidinger, T., Burkart, J., Steiner, G., Reischl, G., Hitzenberger, R., Schwarz, J., and Salma, I. 2012. Comparison of particulate number concentrations in three Central European capital cities. Science of the Total Environment, 433, 418-426.

Boulon, J., Sellegri, K., Venzac, H., Picard, D., Weingarther, E., Wehrle, G., Collaud Coen, M., Bütikofer, R., Flückiger, E., Baltensperger, U. and Laj, P. 2010. New particle formation and ultrafine charged aerosol climatology at a high altitude site in the Alps (Jungfraujoch, $3580 \mathrm{~m}$ a.s.l., Switzerland). Atmos. Chem. Phys., 10, 9333-0349.

Boy, M. and Kulmala, M. 2002. Nucleation events in the continental boundary layer: Influence of physical and meteorological parameters. Atmos. Chem. Phys., 2, 1-16, doi:10.5194/acp-2-12002.

Cheung, H.C., Morawska, L, and Ristovski, Z.D. 2011. Observation of new particle formation in subtropical urban environment. Atmos. Chem. Phys., 11, 3823-3833.

Córdoba-Jabonero, C., Sorribas, M., Guerrero-Rascado, J.L., Adame, J.A.m Hernández, Y., Lyamani, H., Cachorro, V., Gil, M., Alados-Arboledas, L., Cuevas, E. and De la Morena, B.A. 2011. Synergetic monitoring of Saharan dust plumes and potencial impact on surface: a case study of dust transport from Canary Islands to Iberian Peninsula. Atmos. Chem. Phys., 11, 30673091.

Cusack, M., Pérez, N., Pey, J., Wiedensohler, A., Alastuey, A., and Querol, X. 2013. Variability of sub-micrometer particle number size distributions and concentrations in the Western

Mediterranean regional background. Tellus B, 65, 19243,

http://dx.doi.org/10.3402/tellusb.v65i0.19243.

Dal Maso, M., Kulmala, M., Riipinen, I., Wagner, R., Hussein, T., Aalso, P.P. and Lehtinen, K.E.J. 2005. Formation and growth of fresh atmospheric aerosols: eight years of aerosol size distribution data from SMEAR II, Hyytiälä, Finland. Boreal Env. Res., 10, 323-336.

Dall’Osto, M., Monahan, C., Greaney, R., Beows, D.C.S., Harrison, R.M., Ceburnis, D., and O’Dowd, C.D. 2011. A statistical analysis of North East Atlantic (submicron) aerosol size distributions. Atmos. Chem. Phys., 11, 12567-12578.

Erupe, M. E., Benson, D.R., Li, J., Young, L.-H., Verheggen, B., Al-Refai, M., Tahboub, O., Cunningham, C., Frimpong, F., Viffiano, A.A. and Lee, S.-H. 2010. Correlation of aerosol nucleation rate with sulfuric acid and ammonia in Kent, Ohio: An atmospheric observation, J. Geophys. Res., 115, D23216, doi:10.1029/2010JD013942. 
García, M. I., Rodríguez, S., González, Y., and García, R. D. 2014. Climatology of new particle formation events in the subtropical North Atlantic free troposphere at Izaña GAW observatory, Atmos. Chem. Phys., 14, 3865-3881, doi:10.5194/acp-14-3865-2014.

Gómez- Martín, J.C., Gálvez, O., Baeza-Romero, M.T., Ingham, T., Plane, J.M.C., and Blitz, M.A. 2013. On the mechanism of iodine oxide particle formation. Phys. Chem. Chem. Phys., 15, 15612-15622.

Gómez-Moreno, F.J., Sorribas, M., Alnso, E., Artíñano, B., Juncal Bello, V., Piñeiro Iglesias, M., López Mahía, P., Pérez, N., Pey, J., Alastuey, A., García, M.I., Rodríguez, S., Titos, G., Lyamani, H., Alados-Arboledas, L. and De la Morena, B.A. 2013. Medioambiente: partículas ultrafinas y sus instrumentos de medida. Edited by: M. Sorribas, F.J. Gómez-Moreno and B.A. de la Morena. National Institute for Aerospace Technology. ISBN: 978-84-938932-1-7.

Hamed, A., Joutsensaari, J., Mikkonen, S., Sogacheva, L., Dal Maso, M., Kulmala, M., Cavalli, F., Fuzzi, S., Facchini, M.C., Decesari, S., Mircea, M., Lehtinen, K.E.J. and Laaksonen, A. 2007. Nucleation and growth of new particles in Po Valley, Italy. Atmos. Chem. Phys., 7, 355-376.

Hamed, A., Korhonen, H., Sihto, S.-L., Joutsensaari, J., Järvinen, H., Petäjä, T., Arnold, F., Nieminen, T., Kulmala, M., Smith, J.N., Lehtinen, K. E. J. and Laaksonen, A. 2011. The role of relative humidity in continental new particle formation. J. Geophys. Res., 116, D03202, doi:10.1029/2010JD014186.

Hernández-Ceballos, M. A., Adame, J.A., Bolívar, J.P., De la Morena, B.A. 2013. Vertical behaviour and meteorological properties of air masses in the southwest of the Iberian Peninsula (1997-2007). Meteorol. Atmos. Phys. 119,163-175.

Hirsikko, A., Vakkari, V., Tiitta, P., Manninen, H.E., Gagné, S., Laakso, H., Kulmala, M., Mirme, A., Mirme, S., Mabaso, D., Beukes, J.P. and Laakso, L. 2012. Characterization of submicron particle number concentrations and formation events in the western Bushveld Igneous Complex, South Africa. Atmos. Chem. Phys., 12, 3951-3967.

IPCC. 2014. The Physical Science Basis. Contribution of Working Group I to the Fifth Assessment Report of the Intergovernmental Panel on Climate Change, edited by: Stocker T.F., Qin, D., Plattner, G.-K., Tignor, M.M.B., Allen, S.K. et al., Cambridge University Press, Cambridge, UK and New York, USA, ISBN 978-1-107-66182-0.

Jeong, C.-H., Evans, G. J., McGuire, M. L., Chang, R. Y.-W., Abbatt, J. P. D., Zeromskiene, K., Mozurkewich, M., Li, S.-M. and Leaitch, W. R. 2010. Particle formation and growth at five rural and urban sites. Atmos. Chem. Phys., 10, 7979-7995.

Kanawade, V.P., Jobson, B.T., Guenther, A.B., Erupe, M.E., Pressley, S.N., Tripathi, S.N., and Lee, S.-H. 2011. Isoprene suppression of new particle formation in a mixed deciduous forest. Atmos. Chem. Phys., 11, 6013-6027, 2011.

Kim, Y., Yoon, S-C., Kim, S.-W., Kim, K-Y., Lim, H.C., and Ryu, J. 2013. Observation of new particle formation and growth events in Asia continental outflow. Atmos. Environ., 64, 160-168.

Komppula, M., Dal Maso, M., Lihavainen, H., Aalto, P.P., Kulmala, M., and Viisanen, Y. 2003. Comparison of new particle formation events at two locations northern Finland. Boreal Environ. Res., 8, 395-404. 
Korhonen P., Kulmala M., Laaksonen A., Viisanen Y., Mcraw R. y Seinfeld J. H., Ternary Nucleation of $\mathrm{H}_{2} \mathrm{SO}_{4}, \mathrm{NH}_{3}$ y $\mathrm{H}_{2} \mathrm{O}$ in the Atmosphere. 1999. J. Geophys. Res., 104, 26349-26353.

Kulmala, M., Vehkamäki, H., Petäjä, T., Dal Maso, M., Lauri, A., Kerminen, V.-M., Birmili, W., and MacMurry, P.H. 2004a. Formation and growth rates of ultrafine atmospheric particles: a review of observations, Aerosol Science, 35, 143-176.

Kulmala, M., Laakso, L., Lehtinen, K.E.J., Riipinen, I., Dal Maso, M., Anttila, T., Kerminen, V.M., Horrak., U, Vana, M., and Tammet, H. 2004b. Initial steps of aerosol growth. Atmos. Chem.. Physics., 4, 2553-2560, doi:10.5194/acp-4-2553-2004.

Kulmala, M., Lehtinen, K.E.J., and Laaksonen, A. 2006. Cluster activation theory as an explanation of the linear dependence between formation rate of $3 \mathrm{~nm}$ particles and sulphuric acid concentration. Atmos. Chem. Phys., 6, 787-793, doi:10.5194/acp-6-787-2006.

Kulmala, M., Petäjä T., Nieminen, T., Sipilä, M., Manninen, H.E., Lehtipalo, K., Dal Maso, M., Aalto, P.P., Junninen, H., Paasonen, P., Riipinen I., Lehtinen, K.E.J., Laaksonen, A. and Kerminen, V.-M. 2012. Measurements of the nucleation of atmospheric aerosol particles. Nature Protocols, Vol. 7, No. 9.

Kulmala, M., Kontkanen, J., Junninen, H., Lehtipalo, K., Manninen, H.E., Nieminen, T., Petäjä, T., Sipilä, M., Schobesberger, S., Rantala, P., Franchin, A., Jokinen, T., Järvinen, E., Äijälä, M., Kangasluoma, J., Hakala , J. Aalto, P.P., Paasonen, P., Mikkilä, J., Vanhanen, J., Aalto, J., Hakola, H., Makkonen, U., Ruuskanen, T., Mauldin, R.L., Duplissy, J., VehkamÑaki, H., Bäck, J., Kortelainen, A., Riipinen, I., Kurtén, T., Johnson, M.V., Smith, J.N., Ehn, M., Mentel, T.F., Lehtinen, K.E.J., Laaksonen, A., Kerminen, V.-M., and Worsnop, D.R. 2013. Direct observations of atmospheric aerosol nucleation. Science, 339, 943-946.

Knutson, E.O. and Whitby, K.T. 1975. Aerosol classification by electric mobility: apparatus, theory and applications. J. Aerosol Sci., 6, 443-451.

Lunden, M.M., Black, D.R., McKay, M., Rvzan, K.L., Goldstein A.H. and Brown, N.J. 2006. Characteristics of fine particle growth events observed above a forested ecosystem in the Sierra Nevada Mountains of California. Aerosol Science and Technology, 40:373-388.

Lyubovtseva, Y.S., Sogacheva, L., Dal Maso, M., Bonn, B., Keronen, P. and Kulmala, M. 2005. Seasonal variations of trace gases, meteorological parameters, and formation of aerosols in boreal forest. Boreal Environment Research, 10, 493-510.

Mahajan, A.S., Sorribas, M., Gómez Martín, J.C., MacDonald, S.M., Gil, M., Plane, J.M.C. and Saiz-López A. 2011. Concurrent observations of atomic iodine, molecular iodine and ultrafine particles in a coastal environment. Atmos. Chem. Phys., 11, 2545-2555, doi:10.5194/acp-112545-2011.

Petäjä, T., Maulding, R.L., Kosciuch, E., MacGrath, J., Nieminen, T., Paasonen, P., Boy, M., Adamov, A., Kotiaho, T., Kulmala, M. 2009. Surphuric acid and OH concentrations in a boreal forest site. Atmos. Chem. Phys., 9, 7435-7448.

Pikridas, M., Riipinen, I., Hildebrandt, L., Kostenidou, E., Manninen, H., Mihalopoulos, N., Kalivitis, N., Burkhart, J. F., Stohl, A., Kulmala, M., and Pandis, S. N.: New particle formation at a remote site in the eastern mediterranean, J. Geophys. Res., 117, D12205, doi:10.1029/2012jd017570, 2012. 
Prats, N., Cachorro, V.E., Sorribas, M., Mogo, S., Berjón, A., Toledano, C., De Frutos, A.M., De la Rosa, J., Laulainen, N., De la Morena, B.A. 2008. Columnar aerosol properties during "El Arenosillo 2004 summer campaign. Atmos. Environ., 42, 2643-2653.

Querol, X., Alastuey, A., Moreno, T., Viana, M. M., Castillo, S., Pey, J., Rodríguez, S., Artiñano, B., Salvador, P., Sánchez, M., García Dos Santos, S., Herce Garraleta, M.D., Fernández-Patier, R., Moreno-Grau, S., Negral, L., Minguillon, M.C., Monfort, E., Sanz, M.J., Palomo-Marín, R., Pinilla-Gil, E., Cuevas, E., De la Rosa, J. and Sánchez de la Campa, A. 2008. Spatial and temporal variations in airborne particulate matter $\left(\mathrm{PM}_{10}\right.$ and $\left.\mathrm{PM}_{2.5}\right)$ across Spain 1999-2005, Atmos. Environ., 42, 3964-3979.

Shen, X.J., Sun, J.Y., Zhang, Y.M., Wehner, B., Nowak, A., Tuch, T., Zhang, X.C., Wang, T.T., Zhou, H.G., Zhang, X.L., Dong, F., Birmilir, W. and Widensohler. A. 2011. First long-term study of particle Lumber size distributions and new particle formation events of regional aerosol in the North China Plain. Atmos. Chem. Phys., 11, 1565-1580.

Sorribas, M., De la Morena, B.A., Wehner, B., López, J.F., Prats, N., Mogo, S., Wiedensohler, A. and Cachorro, V.E. 2011. On the sub-micron aerosol size distribution in a coastal-rural site at El Arenosillo Station (SW -Spain). Atmos. Chem. Phys., 11, 11185-11206.

Spracklen, D.V., Carslaw, K.S., Kulmala, M., Kerminen, V.-M., Sihto, S.-L., Riipinen, I., Merikanto, J., Mann, G., W., Chipperfield, M.P., Wiedensohler, A., Birmili, W., and Lihavainen, H.: Contribution of particle formation to global cloud condendation nuclei concentrations. Geophys. Res., Lett., 35, L06808, doi:10.1029/2007GL033038, 2008.

Spracklen, D. V., Carslaw, K.S., Merikanto, J., Mann, G.W., Reddington, C.L., Pickering, S., Ogren, J.A., Andrews, E., Baltensperger, U., Weingartner, E., Boy, M., Kulmala, M., Laakso, L., Lihavainen, H., Kivekäs, N., Komppula, M., Mihalopoulos, N., Kouvarakis, G., Jennings, S.G., O’Dowd, C., Birmili, W., Wiedensohler, A., Weller, R., Gras, J., Laj, P., Sellegri, K., Bonn, B., Krejci, R., Laaksonen, A., Hamed, A., Minikin, A., Harrison, R.M., Talbot, R., and Sun, J.: Explaining global surface aerosol number concentrations in terms of primary emissions and particle formation. Atmos. Chem. Phys., 10, 4775-4793, 2010.

Suni, T., Kulmala, M., Hirsikko, A., Bergman, T., Laakso, L., Aalto, P.P., Leuning, R., Cleugh, H., Zegelin, S., Hughes, D., van Gorsel, E., Kitchen, M., Vana, M., Horrak, U., Mirme, S., Mirme, A., Sevanto, S., Twining, J., and Tadros, C. 2008. Formation and characteristic of ions and charged aerosol particles in a native Australian Eucalypt forest. Atmos. Chem. Phys., 8, 129139, doi:10.5194/acp-8-129-2008.

Vakkari, V., Laakso, H., Kulmala, M., Laaksonen, A., Mabaso, D., Molefe, M., Kgabi, N., and Laakso, L. 2011. New particle formation events in semi-clean South African savannah. Atmos. Chem. Phys., 11, 3333-3346.

Vehkamäki, H., Dal Maso, M., Hussein, T., Flanagan, R., Hyvärinen, A., Lauros, J., Merilanto, J.P., Mönkkönen, P., Pihlatie, M., Salminen, K., Sogacheva, L., Thum, T., Ruuskanen, T., M., Keronen, P., Aalto, P.P., Hari, P., Lehtinen, K.E.J., Rannik, Ü, and Kulmala, M. 2004. Atmospheric particle formation events at Värriö measurements station in Finnish Lapland 19982002, Atmos. Chem. Phys., 4, 2015-2023.

Wiedensohler, A., Birmilir, W., Novak, A., Sonntag, A., and coautors. 2012. Mobility particle size spectrometers: harmonization of technical standards and data structure to facilitate high 
quality long-term observations of atmospheric particle number size distributions. Atmos. Meas. Tech., 5, 657-685.

Willeke, K., and Baron, P.A. 1993. Aerosol measurements principles, techniques and applications. Van Nostrand Reinhold, New York, USA, 143-195.

Yli-Juuti, T., Niemnen, T., Hirsikko, A., Aalto, PP., Asm, E., Hörak, U., Manninen, H.E., Patokoski, J., Dal Maso, M., Petäjä, T., Rinne, J., Kulmala, M., and Riipinen, I. 2011. Growth rates of nucleation mode particles in Hyytiälä during 2003-2009: variation with particle size, season, data analysis method and ambient conditions. Atmos. Chem. Phys., 11, 12865-12886.

Young, L.-H, Lee, S.H., Kanawade, V., Hsiao, T.-C., Lee, Y.L., Hwang, B.-F., Liu, Y.-J., Hsu, H.-T., and Tsai, P-J. 2013. New particle growth and shrinkage observed in subtropical environments. Atmos. Chem. Phys., 13, 547-564.

Yue, D. L., Hu, M., Wu, Z. J., Wang, Z. B., Guo, S., Wehner, B., Nowak, A., Achtert, P., Wiedensohler, A., Jung, J. S., Kim,Y. J., and Liu, S. H.. 2009. Characteristics of aerosol size distributions and new particle formation in the summer in Beijing, J. Geophys. Res., 114, D00G12, doi:10.1029/2008JD010894.

Yum, S.S., Roberts, G., Kim, J.H., Song, K., and Kim, D.: Submicron aerosol size distributions and cloud condensation nuclei concentrations measured at Gosan, Korea, during the Atmospheric Brown Clouds-East Asian Regional Experiment 2005. J. Geophys. Res., 112, D22S32, doi:10.1029/2006JD008212, 2007.

\section{Table captions}

Table 1. Statistics on NPF events according to the day-segregation method shown in Fig. 2.

Table 2. The NPF event mean and standard deviation (italic) parameters: start time ( $\left.t_{\text {start }}\right)$ and end ( $\left.t_{\text {end }}\right)$ time, duration $(\Delta t)$, the contribution of coagulation loss flux $\left(F_{\text {coag }}\right)$, formation rate $\left(\mathrm{J}_{14}\right)$, growth rate (mean $\mathrm{GR}$ and $\mathrm{GR}_{14-30}$ ), the maximum particle concentration for the nucleation size fraction $\left(\mathrm{N}_{\mathrm{NUC}}{ }^{\max }\right)$ and the maximum diameter reached during the growth $\left(\mathrm{D}_{\max }\right)$ for each class event (NB, LB and SB). Differences between GR and GR $14-30$ are shown in Section 3.2.1.

Table 3. Pearson's correlation coefficients $(\mathrm{R})$ between $\mathrm{J}_{14}$, GR and $\mathrm{GR}_{14-30}$ and meteorological variables, nucleation particle concentration, the condensation sink, $\mathrm{PM}_{10}$, gas concentrations and radiation levels by Class (NB, LB and SB) events. Moderate correlations of $0.40<\mathrm{R}<0.60$ are bolded in grey and high correlations of $\mathrm{R}>0.6$ are bolded in black. The low statistical significance of $R(p>0.05)$ is shown for values of $R>0.40$ and labelled with a star symbol.

\section{Figure captions}

Fig. 1. (a) Sampling area in the Southwest of Europe and (b) El Arenosillo Station and the Predominance of Biogenic Emissions (PBE) sector, which covers NNW to ESE in a clockwise direction.

Fig. 2. Representative days' classification by means of NPF days and non-event days. *To be considered a NPF event, the particle concentration increases only within the nucleation size fraction $\left(\mathrm{N}_{\mathrm{NUC}}\right)$. 
Fig. 3. Examples of NPF events according to day classification under non-breeze conditions: (a) Class $k$-I event, (b) Class $k$-II event and (c) Undefined event.

Fig. 4. Monthly frequency on total days of: (a) NPF events, (b) Non-Events days, (c) Undefined events (those where new particles of the nucleation size fraction do not grow to larger diameters), and (d) hours with wind blowing from the PBE sector. And monthly frequency on PBE sector days of (e) NPF events and (f) Classes NB, LB and SB events.

Fig. 5. Black squares represent the monthly variation in (a) $J_{14}$, (b) mean $G R$, (c) $N_{\max }$ and (d) $\mathrm{D}_{\text {max }}$. This figure also includes the daily means by class event (black - NB, red - LB and blue SB). The number of events analysed for each month is listed at the top of the Fig. (5a).

Fig. 6. Diurnal behaviour of the main particle variables: (left panel - a and d) particle concentration for the nucleation size fraction $\left(\mathrm{N}_{\mathrm{NUC}}\right)$, (middle panel - $\mathrm{b}$ and e) condensation sink (CS) and (right panel - c and f) $\mathrm{PM}_{10}$ based the NPF event classification. The number of events analysed for each class is also indicated.

Fig. 7. Diurnal behaviour of the main meteorological parameters: (left panel - a and d) temperature, (middle panel - b and e) relative humidity and (right panel - $\mathrm{c}$ and $\mathrm{f}$ ) wind speed by NPF event classification. The number of events analysed for each class is also listed.

Fig. 8. Diurnal behaviour of global solar radiation by NPF event classification. The number of events analysed for each class is also shown.

Fig. 9. Diurnal evolution of trace gases: $\mathrm{O}_{3}$ (a and e), $\mathrm{SO}_{2}$ (b and f), $\mathrm{CO}$ (c and g) and $\mathrm{NO}_{2}$ (d and h) by NPF event classification. The number of events analysed for each class is also shown.

Fig. 10. Diurnal behaviour of the sulphuric acid concentration on the NPF event classification. 


\begin{tabular}{|c|c|c|c|}
\hline & $\mathrm{n}^{\mathrm{o}}$ days & $\begin{array}{c}\text { Frequency } \\
\text { (on total days) }\end{array}$ & $\begin{array}{c}\text { Frequency } \\
\text { (on PBE sector days) }\end{array}$ \\
\hline \multicolumn{4}{|l|}{ Statistics of Total Days } \\
\hline Total Days & 1215 & $100 \%$ & $\overline{--}$ \\
\hline Mixed Sector & 182 & $15 \%$ & -- \\
\hline PBE Sector & 608 & $50 \%$ & $100 \%$ \\
\hline Un-considered & 425 & $35 \%$ & -- \\
\hline \multicolumn{4}{|l|}{ Event days } \\
\hline $\begin{array}{l}\text { Class NB } \\
\text { Class NB-I } \\
\text { Class NB-II }\end{array}$ & $\begin{array}{c}108 \\
55 \\
53\end{array}$ & $8.9 \%$ & $17.8 \%$ \\
\hline $\begin{array}{l}\text { Class LB } \\
\quad \text { Class LB-I } \\
\text { Class LB-II }\end{array}$ & $\begin{array}{c}114 \\
45 \\
69\end{array}$ & $9.4 \%$ & $18.8 \%$ \\
\hline $\begin{array}{l}\text { Class SB } \\
\text { Class SB-I } \\
\text { Class SB-II } \\
\text { Total events }\end{array}$ & $\begin{array}{c}67 \\
32 \\
35 \\
\mathbf{2 8 9}\end{array}$ & $5.5 \%$ & $11.0 \%$ \\
\hline \multicolumn{4}{|l|}{ Non-event days } \\
\hline Class Non-Event-NB & 68 & $5.6 \%$ & $11.2 \%$ \\
\hline Class Non-Event-LSB & 176 & $14.5 \%$ & $28.9 \%$ \\
\hline Total non-events & 244 & $20.1 \%$ & $40.1 \%$ \\
\hline \multicolumn{4}{|c|}{ Days with other classification } \\
\hline Undefined & 75 & $6.1 \%$ & $12.3 \%$ \\
\hline Total Sector Days & 608 & -- & $100 \%$ \\
\hline
\end{tabular}

Table 1 


\begin{tabular}{|c|c|c|c|c|c|c|c|c|c|}
\hline Class & $\begin{array}{c}\text { tstart }_{\text {sto }} \\
\text { (hh:mm) }\end{array}$ & $\begin{array}{c}\text { tend } \\
\text { (hh:mm) }\end{array}$ & $\begin{array}{c}\Delta t \\
\text { hours }\end{array}$ & $\begin{array}{c}J_{14} \\
\left(\mathrm{~cm}^{-3} \cdot \mathrm{s}^{-1}\right)\end{array}$ & $\begin{array}{c}\text { Mean GR } \\
\left(\mathbf{n m} \cdot \mathbf{h}^{-1}\right)\end{array}$ & $\begin{array}{c}\mathrm{GR}_{14-30} \\
\left(\mathrm{~nm}^{\prime} \mathbf{h}^{-1}\right)\end{array}$ & $\begin{array}{c}F_{\text {coag }} \\
\left(\mathrm{cm}^{-3} \cdot \mathrm{s}^{-1}\right)\end{array}$ & $\begin{array}{l}N_{\max } \\
\left(\mathrm{cm}^{-3}\right)\end{array}$ & $\begin{array}{l}D_{\max } \\
(\mathrm{nm})\end{array}$ \\
\hline \multirow[t]{2}{*}{ NB } & $11: 40$ & $22: 20$ & 10.7 & 2.2 & 2.9 & 2.7 & 0.33 & 13850 & 44 \\
\hline & $\pm 01: 30$ & $\pm 03: 10$ & \pm 3.3 & \pm 1.7 & \pm 1.1 & \pm 1.6 & \pm 0.36 & \pm 8350 & \pm 14 \\
\hline \multirow[t]{2}{*}{ LB } & 11:00 & $20: 20$ & 9.5 & 2.5 & 4.5 & 4.3 & 0.30 & 12250 & 52 \\
\hline & $\pm 01: 40$ & $\pm 04: 20$ & \pm 4.5 & \pm 2.3 & \pm 3.0 & \pm 2.8 & \pm 0.38 & \pm 9350 & \pm 20 \\
\hline \multirow[t]{2}{*}{ SB } & $11: 50$ & $18: 00$ & 6.2 & 1.7 & 4.4 & 4.5 & 0.13 & 7660 & 39 \\
\hline & $\pm 01: 25$ & $\pm 04: 00$ & \pm 3.8 & \pm 1.3 & \pm 2.6 & \pm 2.2 & \pm 0.16 & \pm 5200 & \pm 17 \\
\hline \multirow[t]{2}{*}{ All } & $11: 30$ & $20: 40$ & 9.2 & 2.2 & 3.8 & 3.7 & 0.27 & 11830 & 45 \\
\hline & $\pm 01: 40$ & $\pm 04: 10$ & \pm 4.2 & \pm 1.9 & \pm 2.4 & \pm 2.4 & \pm 0.34 & \pm 8410 & \pm 17 \\
\hline
\end{tabular}

Table 2 


\begin{tabular}{|c|c|c|c|c|c|c|c|c|c|}
\hline & \multicolumn{3}{|c|}{ Class NB events } & \multicolumn{3}{|c|}{ Class LB events } & \multicolumn{3}{|c|}{ Class SB events } \\
\hline & $\begin{array}{c}\mathbf{J}_{14} \\
\left(\mathrm{~cm}^{-3} \cdot \mathrm{s}^{-1}\right)\end{array}$ & $\begin{array}{l}\mathbf{G R}_{14-30} \\
\left(\mathrm{~nm} \cdot \mathrm{h}^{-1}\right)\end{array}$ & $\begin{array}{c}\mathbf{G R} \\
\left(\mathrm{nm} \cdot \mathrm{h}^{-1}\right)\end{array}$ & $\begin{array}{c}\mathbf{J}_{14} \\
\left(\mathrm{~cm}^{-3} \cdot \mathrm{s}^{-1}\right)\end{array}$ & $\begin{array}{l}\mathbf{G R}_{14-30} \\
\left(n m^{-1} h^{-1}\right)\end{array}$ & $\begin{array}{c}\mathbf{G R} \\
\left(\mathrm{nm} \cdot \mathrm{h}^{-1}\right)\end{array}$ & $\begin{array}{c}\mathbf{J}_{14} \\
\left(\mathrm{~cm}^{-3} \cdot \mathrm{s}^{-1}\right)\end{array}$ & $\begin{array}{l}\mathbf{G R}_{14-30} \\
\left(\mathrm{~nm} \cdot h^{-1}\right)\end{array}$ & $\begin{array}{c}\mathbf{G R} \\
\left(n m \cdot h^{-1}\right)\end{array}$ \\
\hline $\mathbf{T}^{\mathbf{a}}$ & 0.18 & 0.25 & 0.20 & 0.27 & 0.36 & 0.11 & 0.03 & -0.19 & 0.14 \\
\hline RH & -0.19 & -0.02 & 0.05 & -0.08 & 0.08 & 0.36 & -0.03 & 0.19 & 0.47 \\
\hline WS & -0.24 & -0.05 & 0.19 & -0.30 & 0.19 & 0.10 & 0.00 & 0.05 & -0.18 \\
\hline Nnuc & 0.75 & 0.14 & -0.06 & 0.76 & 0.13 & -0.23 & 0.69 & -0.27 & -0.07 \\
\hline CS & 0.23 & 0.16 & 0.15 & -0.12 & 0.40 & 0.23 & 0.35 & 0.42 & 0.56 \\
\hline $\mathbf{P M}_{10}$ & 0.66 & -0.01 & -0.24 & 0.17 & -0.63 & -0.23 & -0.12 & -0.22 & 0.04 \\
\hline $\mathbf{O}_{3}$ & 0.25 & 0.10 & -0.08 & 0.11 & 0.21 & 0.05 & 0.02 & -0.23 & -0.09 \\
\hline $\mathrm{SO}_{2}$ & 0.05 & 0.35 & 0.01 & -0.32 & 0.23 & $-0.71^{*}$ & -0.12 & 0.14 & 0.36 \\
\hline CO & -0.28 & -0.16 & 0.16 & -0.26 & 0.06 & -0.32 & 0.48 & -0.25 & 0.03 \\
\hline $\mathrm{NO}_{2}$ & 0.06 & -0.10 & 0.21 & -0.24 & 0.25 & -0.05 & 0.30 & 0.13 & 0.19 \\
\hline UVA & 0.38 & 0.12 & 0.03 & 0.47 & 0.40 & 0.05 & 0.19 & -0.01 & 0.07 \\
\hline UVB & 0.38 & 0.14 & 0.11 & 0.47 & 0.48 & 0.18 & 0.13 & -0.03 & 0.12 \\
\hline GLOB & -0.15 & 0.48 & -0.23 & 0.26 & $0.59^{*}$ & 0.35 & 0.53 & 0.03 & 0.00 \\
\hline$\left[\mathrm{H}_{2} \mathrm{SO}_{4}\right]_{\mathrm{GLOB}}$ & -0.18 & 0.03 & -0.07 & $-0.53^{*}$ & -0.32 & $-0.94^{*}$ & $-0.50^{*}$ & $-0.57^{*}$ & $-0.42^{*}$ \\
\hline
\end{tabular}

Table 3 


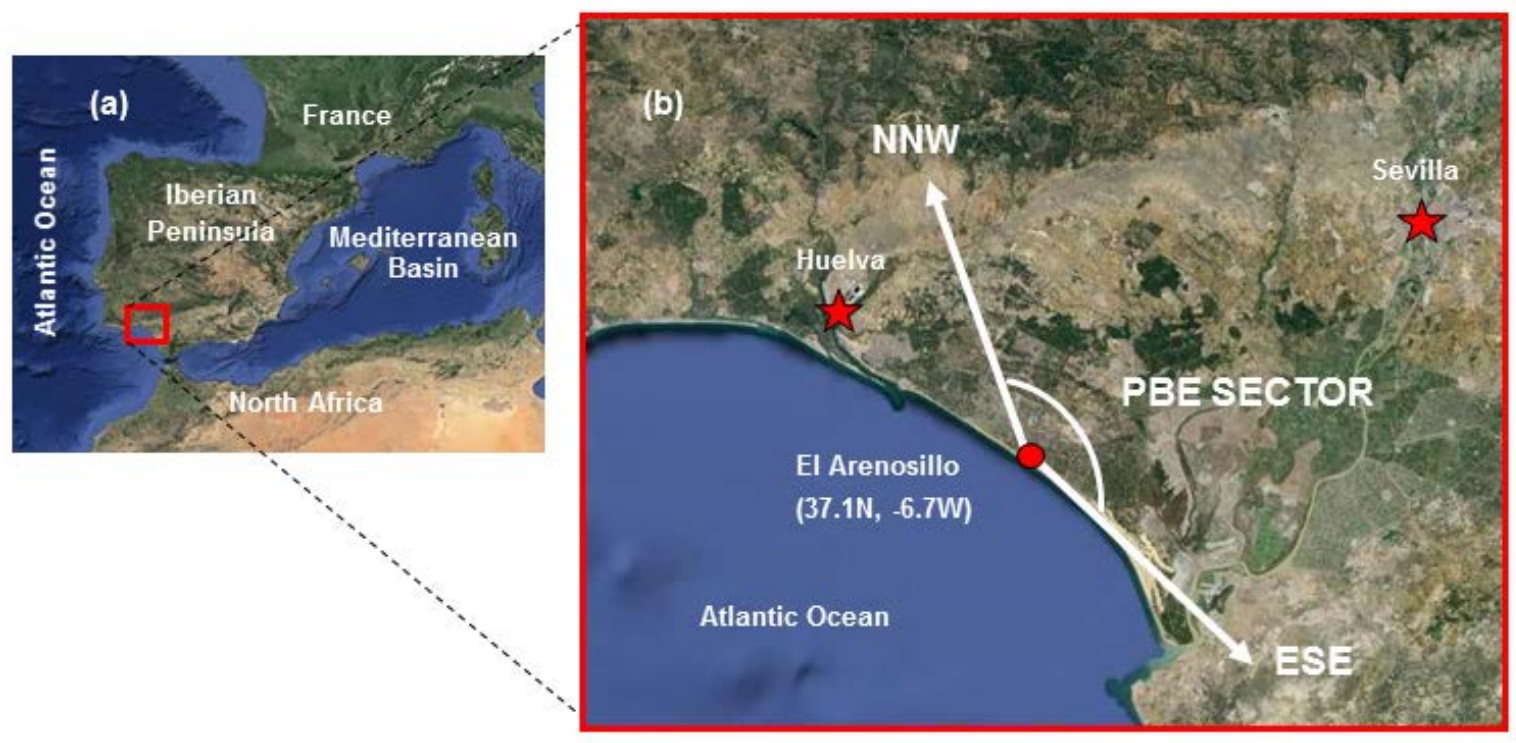

Fig. 1 


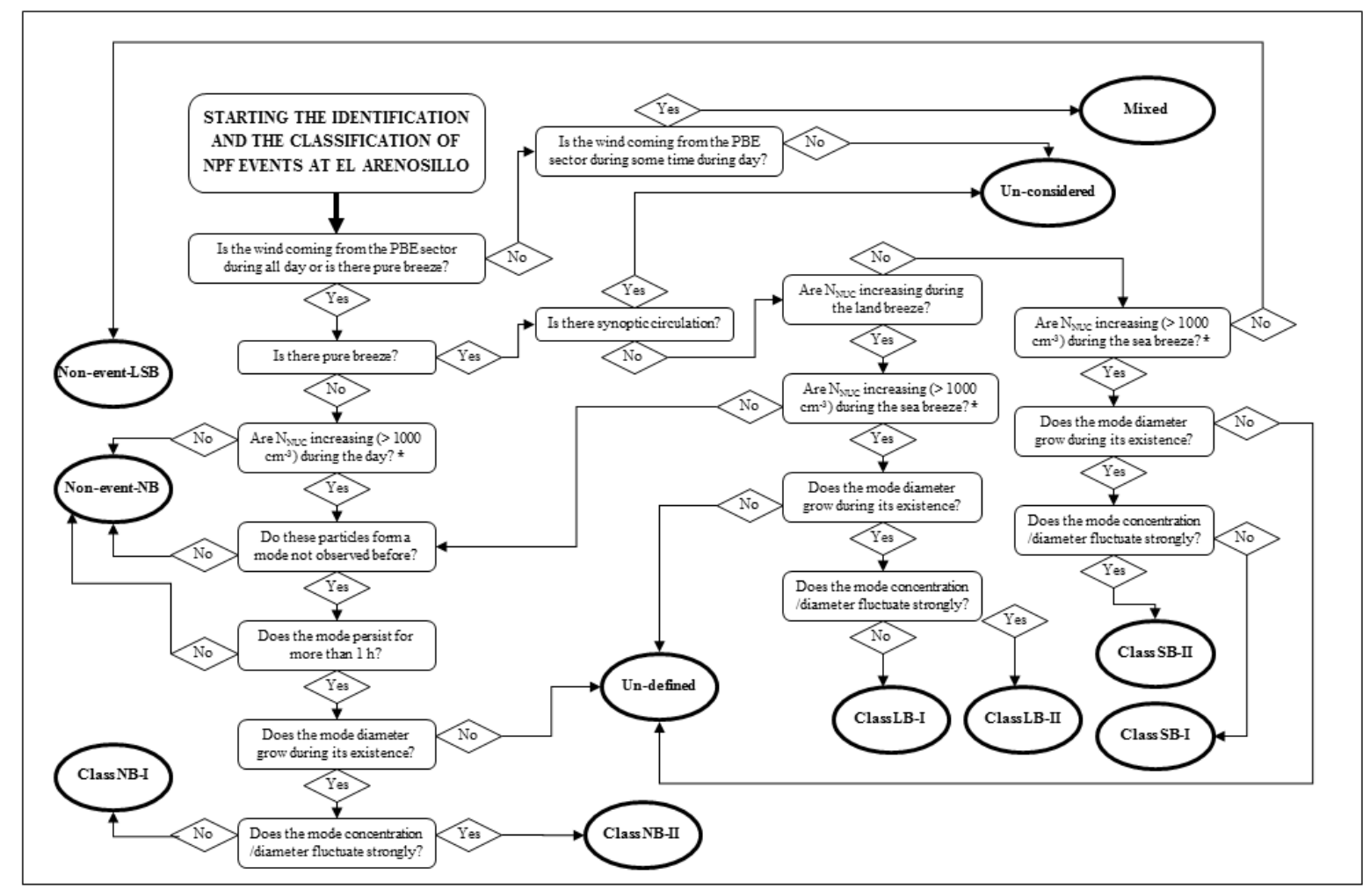

Fig. 2 


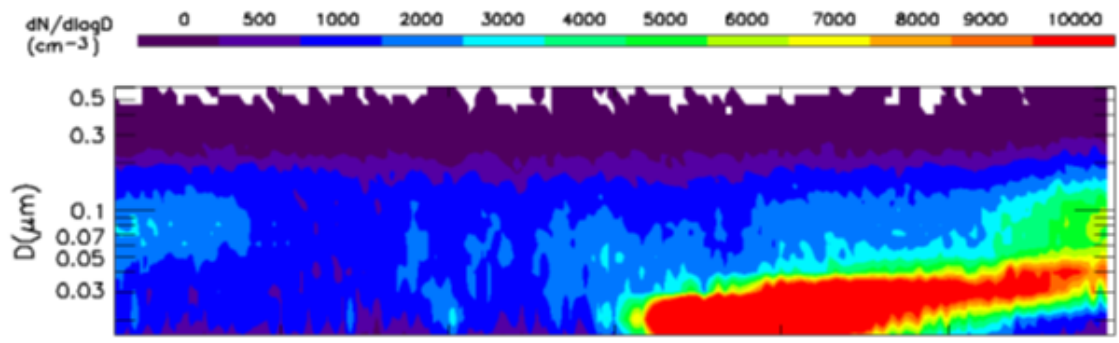

(a)

Class $k$-I

(13 February 2012)

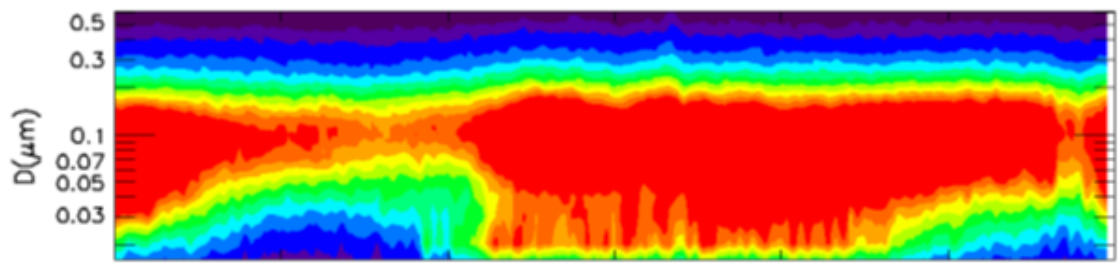

(b)

Class $k$-II

(9 February 2006)

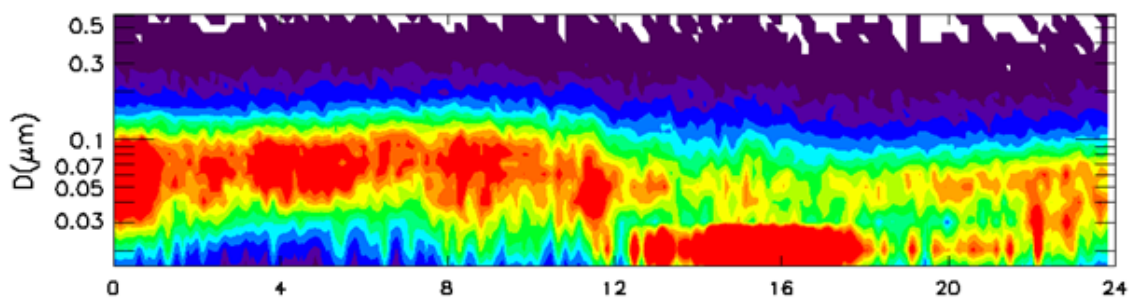

(c)

Undefined

(2 April 2008)

Fig. 3 

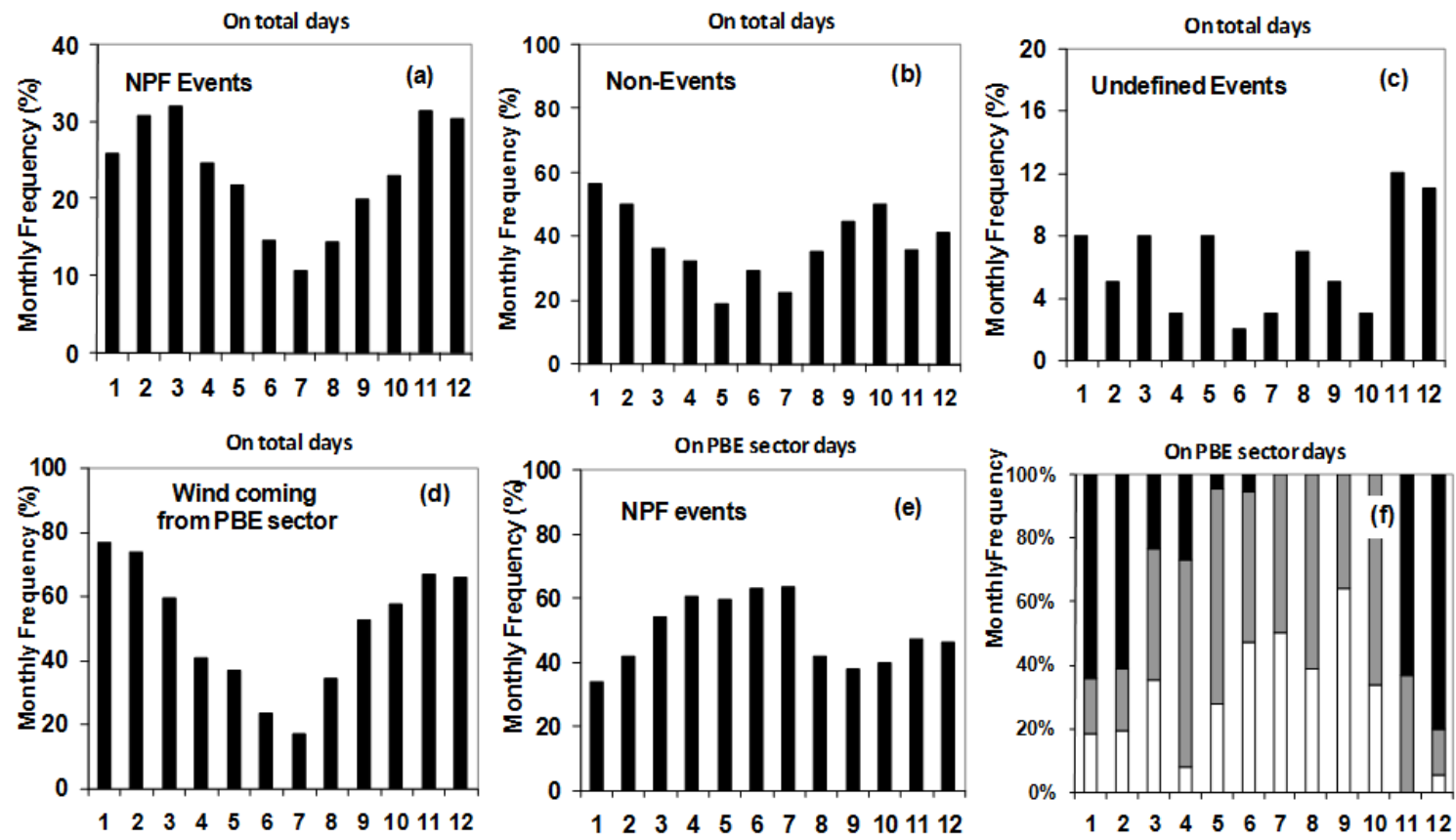

Fig. 4 

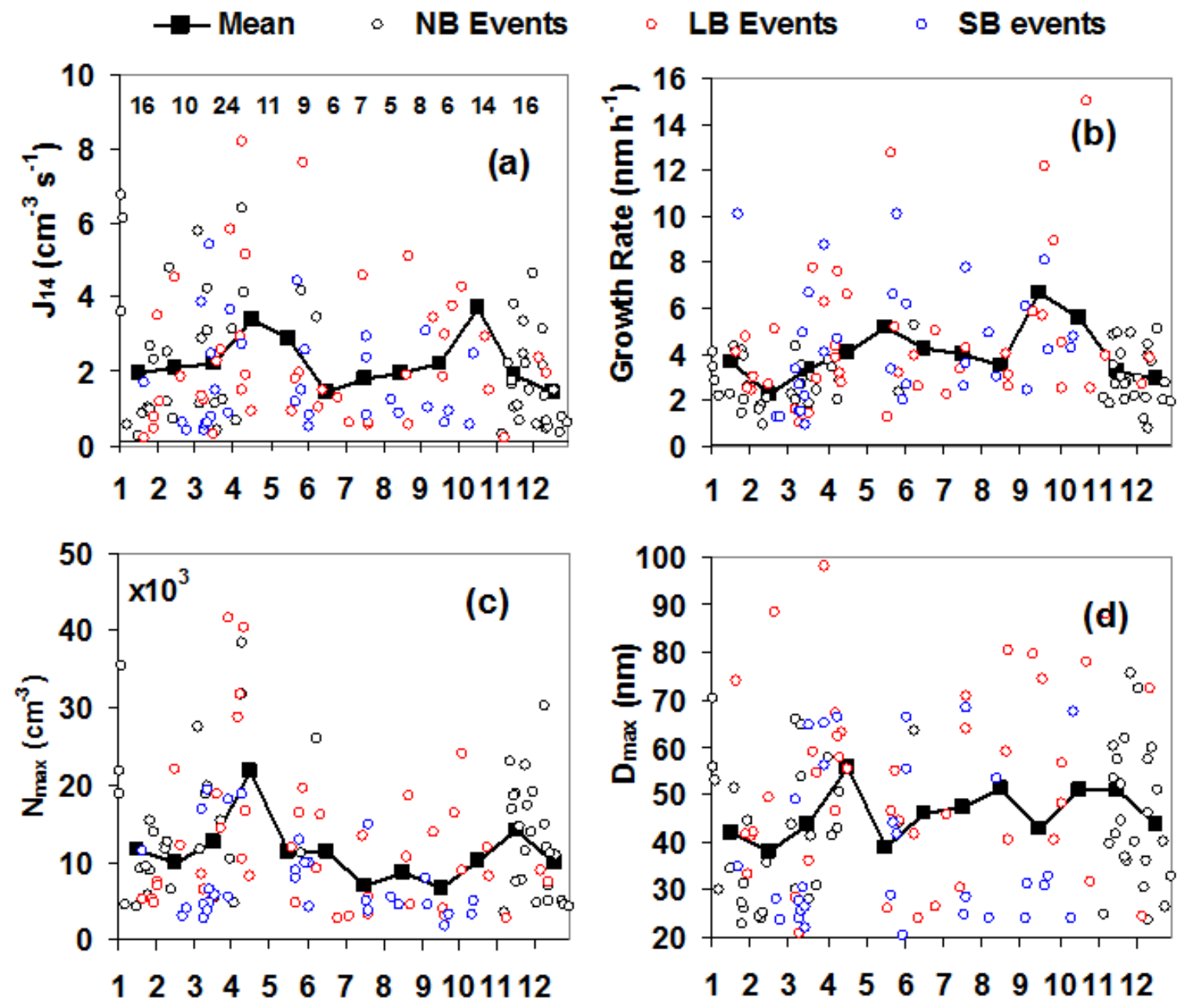

Fig. 5 

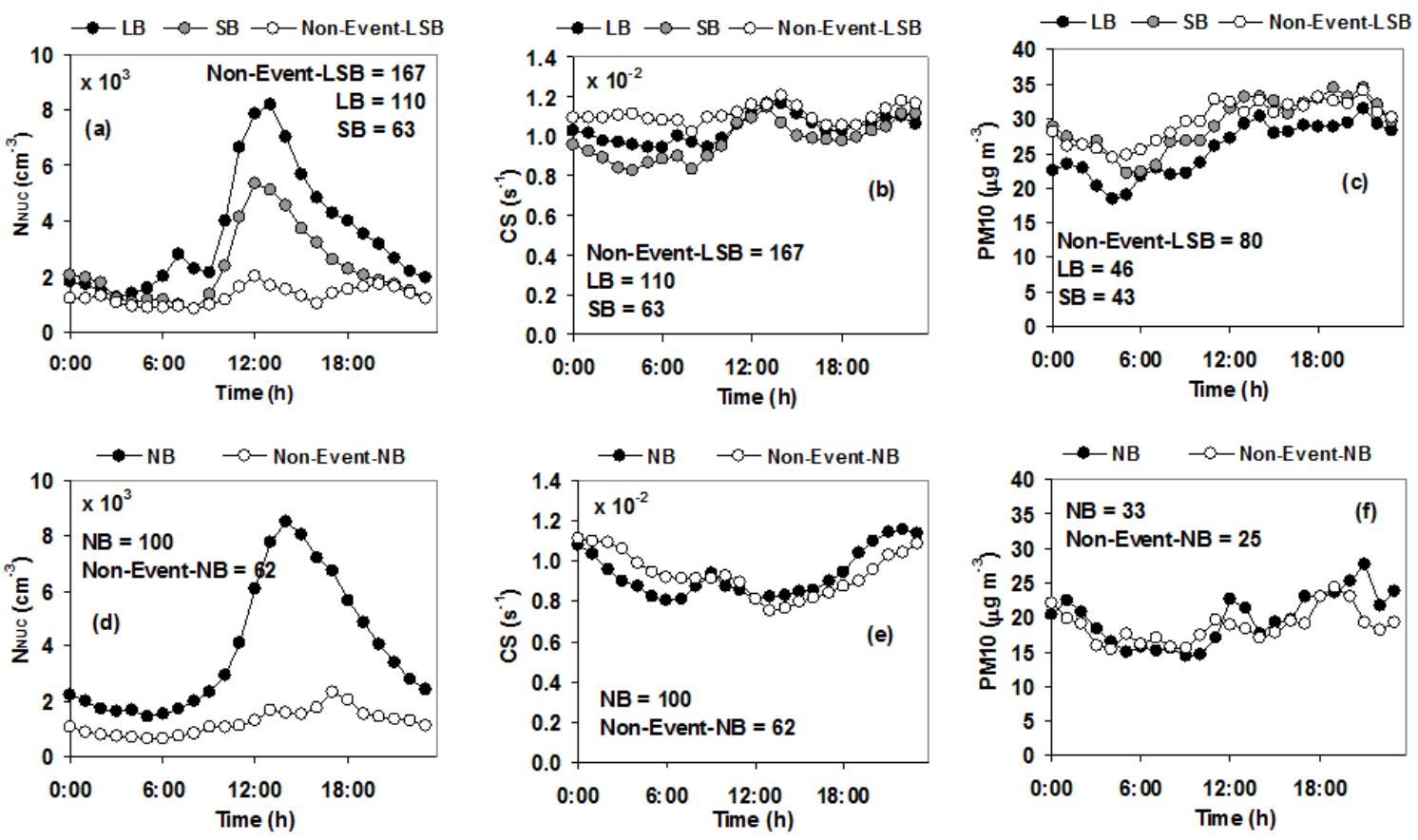

Fig. 6 

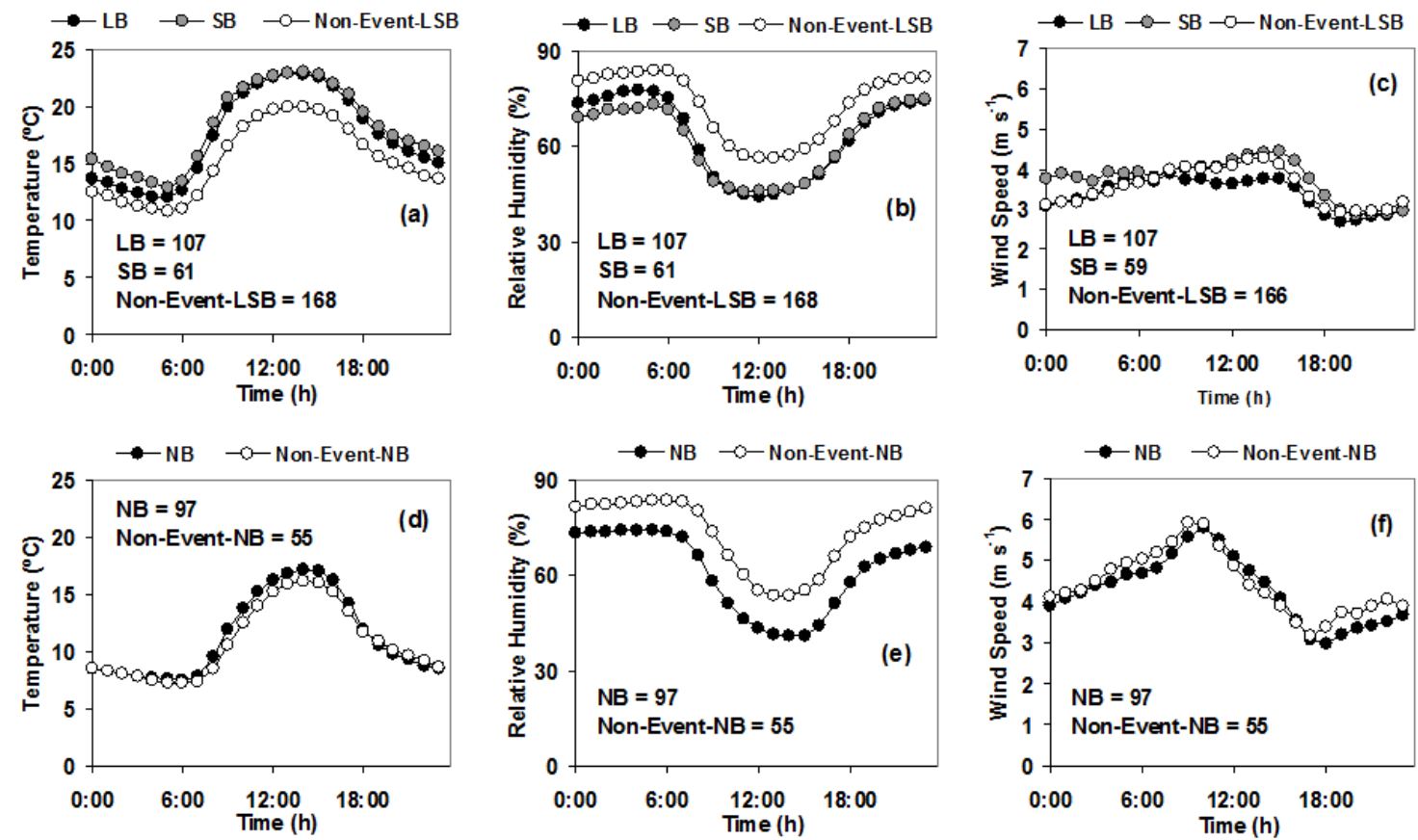

Fig. 7 

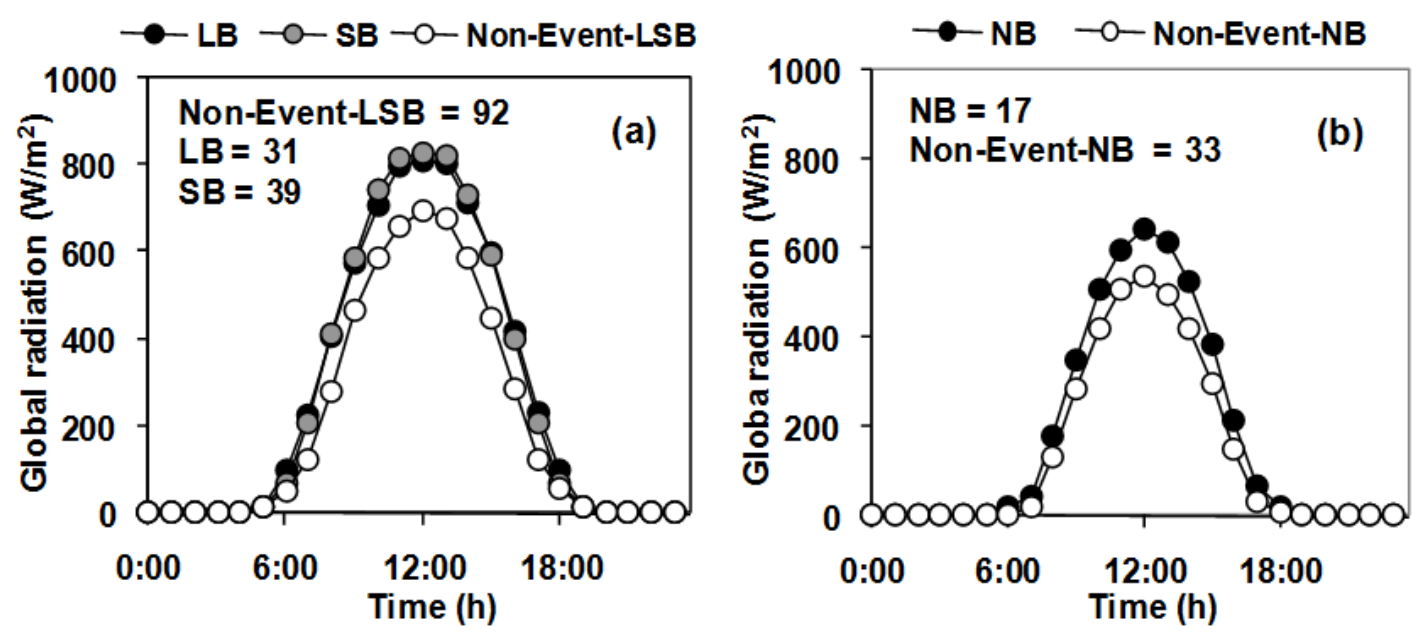

Fig. 8 

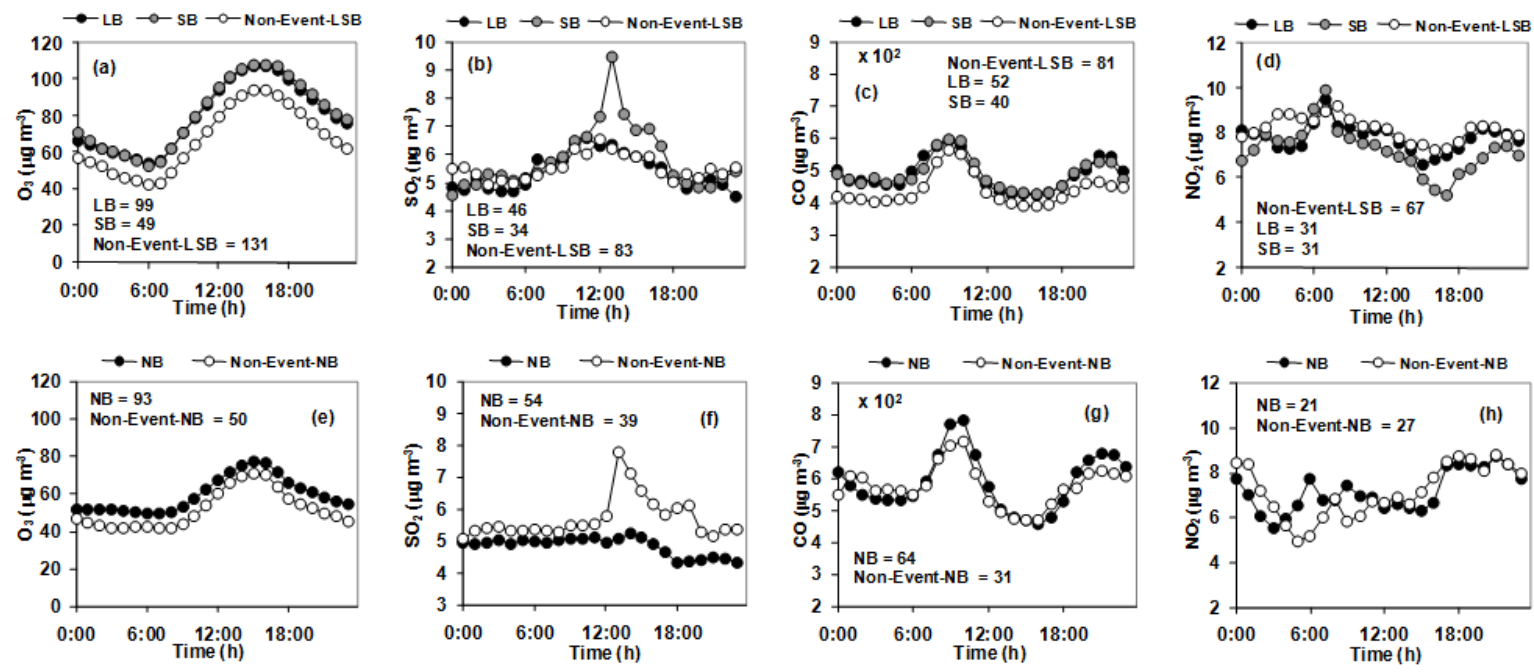

Fig. 9 

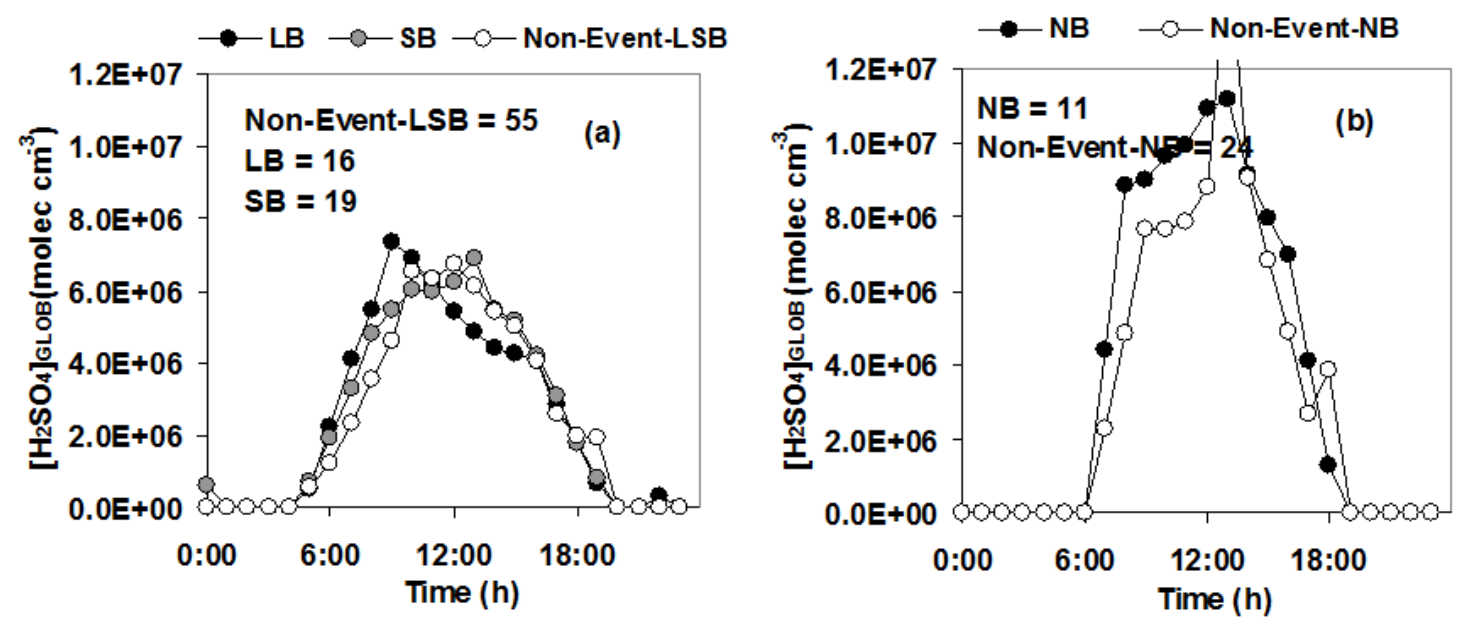

Fig. 10 
